\title{
SOVEREIGN PREEMPTION STATE STANDING
}

\section{Jonathan Remy Nash}

\begin{abstract}
When does a state have standing to challenge the Executive Branch's alleged underenforcement of federal law? The issue took on importance during the Obama Administration, with "red states" suing the Executive Branch over numerous issues, including immigration and health care. The question of state standing has already appeared in important litigation during the first months of the Trump Administration, only with the political orientation of the actors reversed.

This Article argues in favor of sovereign preemption state standing, under which a state would enjoy Article III standing to sue the federal government when (1) the federal government preempts state law in an area, yet (2) the Executive Branch allegedly underenforces the federal law that Congress enacted to address that very same area. Sovereign preemption state standing arises naturally out of the function of states in the federal system. It is grounded upon parens patriae injury - that is, injury to the state's ability to protect its citizens against harm. The federal government can properly preempt state law, on the logic that it then assumes from the state the obligation to protect the state's citizens from harm. Where the Executive Branch then fails adequately to enforce federal law, it leaves the state's citizens unprotected. The state then has Article III standing to sue the federal government on behalf of its citizenry.

The universe of cases where sovereign preemption state standing operates is not large, which should assuage concerns over opening the floodgates of state-federal litigation. Moreover, prudential doctrines can be overlaid such that more cases would be screened out. Although sovereign preemption state standing could conceivably extend to Executive Branch overenforcement, such an application would not square with the functional justification for the doctrine.
\end{abstract}

AUTHOR-Robert Howell Hall Professor of Law, Emory University School of Law. For valuable comments on drafts of the paper, I am grateful to Tara Leigh Grove, Kay Levine, Robert Mikos, Rafael Pardo, and Shannon Roesler. I also benefited from participation on panels on state standing at the 2016 southern regional meeting of the National Association of Attorneys General and at a Public Policy Conference on "Environmental 
Law in the Administrative State" hosted by the Center for the Study of the Administrative State at the Antonin Scalia Law School at George Mason University.

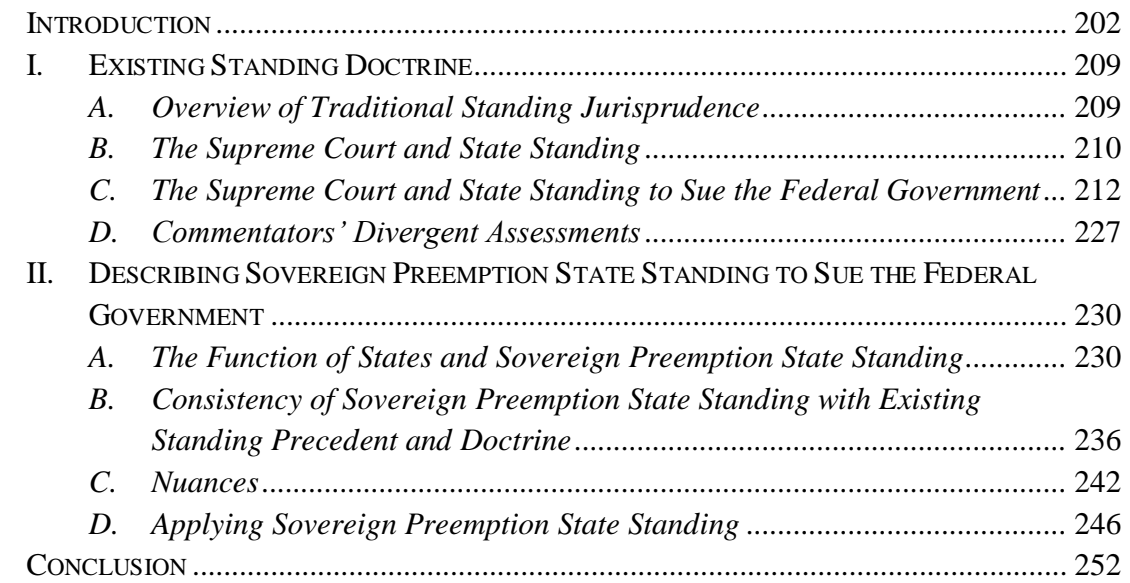

\section{INTRODUCTION}

What standard must a state meet to establish proper standing in federal court to sue the United States? The traditional test for Article III standing calls for plaintiffs to establish an "injury in fact." Most plaintiffs assert an economic injury in fact. Yet, while states sometimes can rest a lawsuit on a valid economic injury, ${ }^{2}$ often the types of complaints states have-and hence the injuries they can allege - are not economic. Rather, these injuries may go to the states' very sovereignty and ability to protect their citizens. Such noneconomic injuries are perhaps especially likely to abound where states assert alleged injuries suffered at the hands of the federal government.

The Supreme Court has, over time, allowed states greater berth in suing the federal government. It has recognized the standing of states to sue for direct constitutional injuries allegedly imposed by action of the federal

\footnotetext{
${ }^{1}$ See, e.g., Lujan v. Defs. of Wildlife, 504 U.S. 555, 560 (1992). The standard test for standing includes two other elements as well: causation and redressability. See id. at 560-61; infra notes 39-44 and accompanying text.

${ }^{2}$ See, e.g., Hawaii v. Standard Oil Co. of Cal., 405 U.S. 251, 253 (1972) (suit-ultimately unsuccessful on the merits - under the antitrust laws for damages state suffered in its "proprietary capacity").
} 
government. ${ }^{3}$ And, while it has never directly so held, its cases can be read to support the normatively desirable notion that states have standing to challenge the validity of preemption of their laws by the federal government. ${ }^{4}$

Yet, with the tremendous growth of federal administrative agencies, states may suffer injuries at the hands of the federal government that neither of these lines of cases cover. Regulatory actions by the Obama Administration wound up prompting federal lawsuits by collections of socalled "red states," with the states arguing that the Executive Branch was not enforcing the laws as Congress had written them. ${ }^{5}$ And, as shown by state challenges to President Trump's executive orders on immigration, it appears that "blue states" stand ready to employ a similar strategy against the Trump Administration. ${ }^{6}$

The important question thus arises: Does a state have standing to raise a claim that the Executive Branch is underenforcing the law as enacted by Congress? Here, the muddled state of the law provides no clear path to state standing. Much of this confusion stems from the Supreme Court's 2007 opinion in Massachusetts v. EPA. ${ }^{7}$ There, the Court held that the State of Massachusetts had standing to challenge the U.S. EPA's refusal-and assertion of an absence of statutory power-to regulate greenhouse gas tailpipe emissions. ${ }^{8}$ The five-Justice majority concluded that, as sovereigns, states enjoy "special solicitude" in the standing calculus. ${ }^{9}$ Yet the actual role that sovereignty played in the Court's conclusion remains murky. Despite the Court's recitation of sovereignty as a factor in its analysis, the Court, in the end, emphasized Massachusetts's ownership of coastal property-property that would disappear if the predicted effects of climate

\footnotetext{
${ }^{3}$ See infra Section I.C.3.a.

${ }^{4}$ See Tara Leigh Grove, When Can a State Sue the United States?, 101 CoRnell L. Rev. 851, 880-85 (2016) (relying upon, among other cases, Missouri v. Holland, 252 U.S. 416 (1920), and Gonzales v. Oregon, 546 U.S. 243 (2006), to conclude that a state has standing to challenge preemption of its law by the federal government).

5 See, e.g., United States v. Texas, 136 S. Ct. 2271 (2016) (challenge by states to Executive Branch enforcement of the federal immigration laws); see also infra notes 12-22 and accompanying text (discussing the case).

${ }^{6}$ See Adam Nagourney, Expecting Trouble, California Picks Up Some Legal Muscle, N.Y. TIMES, Jan. 5, 2017, at A14 ("Girding for four years of potential battles with President-elect Donald J. Trump, Democratic leaders of the California Legislature announced ... that they had hired Eric H. Holder Jr., who was attorney general under President Obama, to represent them in any legal fights against the new Republican White House."); Vivian Yee, To Combat Trump, Democrats Look to G.O.P. Tactic: Lawsuits, N.Y. TIMES, Dec. 15, 2016, at A1.

7549 U.S. 497 (2007).

8 Id. at 518-19.

${ }^{9} \mathrm{Id}$. at 520 .
} 
change came to pass - as the basis for finding that Massachusetts had standing. ${ }^{10}$ The actual basis on which the Court rested Massachusetts's standing thus seems like a traditional economic, not sovereignty-based, injury. On this reading, the "special solicitude" that the majority afforded states goes not to any aspect of state sovereignty as such but rather reduces the stringency of the ordinary - and still applicable - economic standard test for injury. ${ }^{11}$

The current state of the law thus puts states seeking to sue the United States in the difficult position of trying either (1) to shoehorn what probably is not a traditional economic injury into that pigeonhole; (2) to assert an injury to sovereignty based on precedent that provides only limited, and murky, support for the validity of such an injury in the standing inquiry; or (3) both. The law thus remains unclear and impoverished in terms of the bases on which states have standing to sue in federal court.

This perplexing post-Massachusetts $v$. EPA landscape has shaped efforts by states to challenge the federal government's approach to immigration enforcement. Numerous states - including most prominently the State of Texas ${ }^{12}$-attempted to establish standing to contest implementation of a directive issued by the Department of Homeland Security. ${ }^{13}$ The directive-Deferred Action for Parents of Americans and Lawful Permanent Residents (DAPA) ${ }^{14}$ - was designed to provide parents of citizens and lawful permanent U.S. residents legal presence within the United States. ${ }^{15}$ Texas claimed it had standing to pursue the challenge to

10 Id. at $522-23$.

11 See id. at 539 (Roberts, C.J., dissenting).

12 Twenty-five other States joined the complaint. Texas v. United States, 809 F.3d 134 (5th Cir. 2015), aff'd by an equally divided Court, 136 S. Ct. 2271 (2016). However, insofar as "the presence of one party with standing is sufficient to satisfy Article III's case-or-controversy requirement," Rumsfeld v. Forum for Acad. \& Institutional Rights, Inc., 547 U.S. 47, 52 n.2 (2006), the conclusion by the district court and court of appeals that Texas had standing was a sufficient basis to conclude that federal court standing was proper over the entire case. For ease of exposition, I refer in the text solely to Texas's arguments in favor of standing.

13 See Texas v. United States, 86 F. Supp. 3d 591, 604 (S.D. Tex. 2015), aff'd, 809 F.3d 134 (5th Cir. 2015), aff'd by an equally divided Court, 136 S. Ct. 2271 (2016).

14 See Memorandum from Jeh Charles Johnson, Sec'y, Dep't Homeland Sec., to León Rodríguez, Dir., U.S. Citizenship \& Immigration Servs., et al., Exercising Prosecutorial Discretion with Respect to Individuals Who Came to the United States as Children and with Respect to Certain Individuals Who Are the Parents of U.S. Citizens or Permanent Residents 4-5 (Nov. 20, 2014), https://www.dhs.gov/sites/default/files/publications/14_1120_memo_deferred_action.pdf [https://perma.cc/EN7A-W3FT].

15 More precisely, the Department of Homeland Security sought to expand an earlier directive and implement a new directive. In 2012, the Department implemented the Deferred Action for Childhood Arrivals program (DACA), under which the Department would exercise its prosecutorial discretion and 
DAPA because it would have to issue driver's licenses to DAPA beneficiaries. Consistent with the muddled jurisprudence, Texas spun this basis for standing - and the courts below accepted this basis for standingas both economic and sovereignty based. For example, the lower courts expressly found that the issuance of new driver's licenses would impose on Texas a cost of at least "several million dollars." 16 At the same time, the appeals court found that the need to issue new driver's licenses also qualified as an injury to state sovereignty, reasoning that "DAPA affects the states' 'quasi-sovereign' interests by imposing substantial pressure on them to change their laws, which provide for issuing driver's licenses to some aliens and subsidizing those licenses." 17

While the Supreme Court ultimately affirmed the decision below by tie vote without opinion, ${ }^{18}$ the dialogue during oral argument in the case amply demonstrates similar attempts to cast Texas's injury as alternatively economic and sovereignty based. The Texas Solicitor General explained: "First, we're raising financial harms from our own State's fisc. That's not a parens patriae. And we're also raising sovereign harms, and that's Massachusetts v. EPA. We have ceded to the Federal government the authority to determine who's lawfully present within the borders of the 26 States." 19

Oral argument also confirmed profound confusion over whether the Massachusetts v. EPA opinion's invocation of the states' entitlement to "special solicitude" meant that standing was based on economic or sovereignty-based injury. As noted just above, the Texas Solicitor General considered Massachusetts to have dealt with states' sovereignty interests. In response to a reference by Chief Justice John Roberts to "special solicitude" in Massachusetts v. EPA, the attorney for the intervenors (individuals claiming uncertainty as a result of the invalidation of DAPA) stated: "In that case, it was not a financial claim.... [I]t was a claim related to the State's quasi-sovereign interest over land." ${ }^{20}$ And Justice

\footnotetext{
defer immigration enforcement as to certain young people on a case-by-case basis, provided that they passed background checks. See Texas v. United States, 809 F.3d at 146-47. Then, in 2014, the Department implemented DAPA. DAPA both (1) expanded the pool of people eligible for treatment under DACA and extended the time period in which enforcement would be deferred, and (2) created the new DAPA program that would extend treatment similar to DACA to certain parents of U.S. citizens and lawful permanent residents. See id. at 146-49.

${ }^{16} I d$. at 155 (quoting Texas v. United States, 86 F. Supp. 3d at 617).

17 Id. at 153.

18 United States v. Texas, 136 S. Ct. 2271 (2016).

19 Transcript of Oral Argument at 62-63, United States v. Texas, 136 S. Ct. 2271 (2016) (No. 15674).

${ }^{20} I d$. at 40.
} 
Stephen Breyer asserted: "[A]s far as Massachusetts is concerned ... that was their own coastline. And that's not money. That's the physical territory belonging to Massachusetts. And, of course, they have standing to protect that." ${ }^{21}$ These statements are consistent with a sovereignty-based understanding of Massachusetts. In contrast, the U.S. Solicitor General seemed to understand Massachusetts as simply expanding the existing basis for standing, i.e., standing based on economic injury. When Chief Justice Roberts asked how the injury in the case at bar was "any more indirect and speculative" than the injury in Massachusetts v. EPA, the U.S. Solicitor General explained: "States got special solicitude and were allowed to sue in a manner where, under Article III, they normally wouldn't be able to sue." 22

The efforts by judges and advocates to fit Texas's driver's license injury into the economic pigeonhole for standing (even as arguably expanded by Massachusetts's special solicitude) or into the pure sovereignty-based pigeonhole is a misguided exercise. But it is the inexorable result of the Court's muddled precedent.

In this Article, I advance a blueprint for what I term "sovereign preemption state standing" to sue the federal government. Sovereign preemption state standing is, I argue, consistent with the Court's precedents and serves to clarify them. It rests upon an injury that is neither economic nor purely sovereign; rather, it is a form of quasi-sovereign — or "parens patriae" - injury. ${ }^{23}$ A state asserts a parens patriae injury on behalf of its citizenry. Here, that injury arises from a combination of (1) the Executive Branch underenforcing federal statutory law, and (2) the federal government actively preempting state law.

More specifically, sovereign preemption state standing arises when, at a minimum, the following conditions are met. First, the state must allege that the Executive Branch has underenforced the federal law in a way that is inconsistent with a governing statute. Second, the state must be able to point to preemption of state law; in particular, either the preemption of state law must be obvious and clear from a federal statute or the federal government must have previously sought, or be concurrently seeking, to preempt state law. In addition, there must be a nexus between the area of preemption and the area in which the Executive Branch is allegedly underenforcing federal law.

Sovereign preemption state standing arises naturally out of the function of states in the federal system. The Constitution recognizes the

\footnotetext{
${ }^{21} I d$. at 62 .

${ }^{22} I d$. at 18

23 "Parens patriae" is Latin for "parent of the country." Alfred L. Snapp \& Son, Inc. v. Puerto Rico ex rel. Barez, 458 U.S. 592, 600 (1982).
} 
continuing importance of states and preserves much of the states' police power authority. ${ }^{24}$ The Constitution thus validates the ongoing role of states in protecting the health and well-being of their citizens..$^{25} \mathrm{~A}$ state cannot fulfill this role when the federal government preempts state law; still, the state's citizens receive protection if the federal government puts in place a federal law to fill the void left by the preemption of state law. Indeed, the constitutional logic is that the federal government acts in the stead of the state governments to protect the nation's citizenry. In effect, the state government and the federal government both have parens patriae status; either can validly protect the interest of the people. A state has no sovereign preemption standing to challenge the mere fact that the federal government has opted to supersede the state as regulatory parens patriae on a particular issue. ${ }^{26}$

However, this logic breaks down when, notwithstanding Congress's decision to put in place a federal law, the Executive Branch underenforces that law. ${ }^{27}$ Now, the state can argue that the federal government is not properly exercising the protective power that the state effectively delegated to the federal government under the Constitution. And the injury to its citizenry that results from that underenforcement creates the state's basis for sovereign preemption state standing.

Sovereign preemption state standing broadly aligns with prior precedent governing state standing to sue the federal government. ${ }^{28}$ Additionally, it leaves undisturbed the view-recognized by Professors Ann Woolhandler and Michael Collins and by Professor Stephen Vladeck - that a state should have standing to sue the national government for a direct injury it has suffered. ${ }^{29}$ And it is consistent with the conception

24 See, e.g., Bond v. United States, 134 S. Ct. 2077, 2086 (2014) ("In our federal system, the National Government possesses only limited powers; the States and the people retain the remainder. The States have broad authority to enact legislation for the public good-what we have often called a 'police power.'”) (quoting United States v. Lopez, 514 U.S. 549, 567 (1995)).

25 See id.

26 See infra Section II.C.2 (discussing the possibility of extending sovereign preemption state standing to settings of Executive Branch overenforcement of federal statutory law).

Furthermore, sovereign preemption state standing can be contracted or expanded by making the nexus requirement - that is, the degree to which the area of state law preempted by the federal government aligns with the area of law allegedly underenforced by the Executive Branch-more or less exacting. See infra Section II.C.1.

27 The Executive Branch might argue that it is not systematically underenforcing the federal statutory scheme but that it is simply judiciously exercising prosecutorial discretion. Such an argument might be a valid defense on the merits but would not defeat sovereign preemption state standing based upon a state's allegation of underenforcement.

28 See infra Section II.B.

29 See Stephen I. Vladeck, States' Rights and State Standing, 46 U. RICH. L. REV. 845, 857-65 (2012); Ann Woolhandler, Governmental Sovereignty Actions, 23 WM. \& MARY BILL RTS. J. 209, 217- 
of standing, advanced by Professor Tara Leigh Grove, that allows a state to challenge the validity of federal government preemption of state law. ${ }^{30}$ Sovereign preemption state standing provides the next logical step: It provides standing where, even if the preemption is valid, the Executive Branch fails to enforce the federal law that takes the place of preempted state law. Sovereign preemption state standing thus provides what other theories do not: a consistent logical lens through which to view the Court's decision in Massachusetts v. EPA.

My understanding of a sovereign injury sufficient to confer on a state standing to sue the federal government differs substantially fromalthough it is not necessarily entirely incompatible with - the approach taken by some other scholars on this issue. As noted just above, it is consistent with Professor Grove's advocacy of state standing to sue over the validity of federal government preemption of state law. ${ }^{31}$ However, it conflicts with Professor Grove's argument that states lack standing to challenge problems of horizontal separation of powers. ${ }^{32}$ Sovereign preemption state standing also bears no logical relationship to Professor Shannon Roesler's argument that a state's standing to sue the federal government should turn on whether the state's suit challenges a federal program that includes the states in its administration. ${ }^{33}$ While theoretically my approach can coexist with Professor Roesler's, the analysis below suggests that the two theories provide standing in largely nonoverlapping sets of cases. ${ }^{34}$ In other words, operation of both theories would admit numerous cases into the federal courts.

The universe of cases where sovereign preemption state standing operates is not large, which should assuage commentators-like Professors Woolhandler and Collins and Professor Vladeck-who favor limiting the bases on which states can sue the federal government. ${ }^{35}$ Moreover, courts could overlay prudential doctrines - that is, subconstitutional standing

18 (2014); Ann Woolhandler \& Michael G. Collins, State Standing, 81 VA. L. REV. 387, 493-94 (1995).

${ }^{30}$ See Grove, supra note 4, at 880-85.

31 See supra text accompanying note 30.

32 See Grove, supra note 4, at 885-99 (arguing that states lack standing to sue over the federal Executive's enforcement of federal law because, by virtue of the Executive's action, the states suffer no injury different from any other member of society).

33 See Shannon M. Roesler, State Standing to Challenge Federal Authority in the Modern Administrative State, 91 WASH. L. REV. 637, 677-702 (2016).

34 See infra notes 207-09 and accompanying text.

35 See Vladeck, supra note 29, at 874; Woolhandler, supra note 29, at 236; Woolhandler \& Collins, supra note 29 , at $490-93$. 
doctrines $^{36}$ - on top of sovereign preemption so that more cases would be screened out. ${ }^{37}$ Alternatively, courts could also construe sovereign preemption state standing somewhat more broadly so that it applies not only to the setting of Executive Branch underenforcement, but to the setting of horizontal federal disagreement in general-i.e., to the setting of Executive Branch overenforcement as well. ${ }^{38}$

This Article proceeds as follows. Part I sets out the basics of relevant standing doctrine, including the standing of states. It highlights the shortcomings and confusion in the existing law governing state standing to sue the United States. Part II turns to sovereign preemption state standing. It first derives the doctrine from the function of states under the constitutional design. Second, it demonstrates its consistency with existing precedent. Next, it considers possible nuances in the application of the doctrine. Last, it explores how sovereign preemption state standing might, and might not, apply in actual federal court cases (and in one hypothetical case).

\section{EXISTING STANDING DOCTRINE}

This Part explores the jurisprudence governing state standing to sue the federal government. Section A begins with a brief overview of traditional standing jurisprudence - that is, the rules governing standing in a typical case where the plaintiff is not a state and the defendant is not (or need not be) the federal government or a federal actor. Section B narrows the focus by looking at the standing of states to invoke the jurisdiction of the federal courts. Section $\mathrm{C}$ narrows the focus further still by examining the Supreme Court's treatment of standing where a state has tried to sue the federal government. Finally, Section D surveys the state of the law as other commentators have tried to crystallize it.

\section{A. Overview of Traditional Standing Jurisprudence}

Standing limits the ability of litigants to litigate, and in particular for plaintiffs to bring lawsuits, in the federal courts. Standing consists of two components. Its core, "constitutional standing," emanates from Article III

\footnotetext{
36 See Jonathan Remy Nash, A Functional Theory of Congressional Standing, 114 Mich. L. REV. 339, 346 (2015). But see Lexmark Int'1, Inc. v. Static Control Components, Inc., 134 S. Ct. 1377, 138687 (2014) (explaining that some standing requirements to which the Court previously had referred as "prudential" were better understood as statutory requirements for standing).

37 See infra Section II.C.4 (discussing the application of the bar against "generalized grievances," the requirement that Congress have created a statutory cause of action, and the "political question doctrine" to cases where sovereign preemption state standing otherwise might inhere).

38 See infra text accompanying notes 87-90 (discussing cases where the Supreme Court found that states lacked standing when they raised "competing parens patriae" claims).
} 
of the Constitution. In addition, other doctrines-some constitutional and some subconstitutional (or prudential) ${ }^{39}$ - further empower federal courts to decline to recognize the standing of certain plaintiffs to bring lawsuits against certain defendants in certain circumstances.

The Supreme Court has made clear that the Constitution requires a plaintiff to make three showings in order establish proper Article III standing: (1) "injury in fact," (2) a causal link between that injury and the conduct complained of, and (3) redressability..$^{40}$ The "injury in fact" prong demands that the plaintiff show that he or she has suffered "an invasion of a legally protected interest which is (a) concrete and particularized; and (b) 'actual or imminent, not "conjectural" or "hypothetical.","' ${ }_{41}$ Causation requires the plaintiff to establish that the injury resulted from the action of the defendant and not from independent action by a third party. ${ }^{42}$ Finally, the "redressability" prong requires a plaintiff to show that it is "'likely,' as opposed to merely 'speculative,' that the injury will be 'redressed by a favorable decision." "43 From the plaintiff's perspective, the "injury in fact" prong "drives the standing analysis." 44

\section{B. The Supreme Court and State Standing}

In their exhaustive study of state standing, Professors Woolhandler and Collins highlight the limited number and categories of cases in which states historically had standing to invoke the jurisdiction of the federal courts. ${ }^{45}$ They delineate how, through the nineteenth century, a state had standing to sue where either (1) the state sought legal help to resolve a state interest truly sovereign in nature (such as resolving a boundary dispute), or (2) the state asserted a common law claim. ${ }^{46}$ Professors Woolhandler and Collins conclude that beyond the Republic's first century, except for state sovereignty interests, states enjoyed no basis for standing in federal court beyond what was available to ordinary nonstate litigants. ${ }^{47}$ In other words,

\footnotetext{
39 See supra note 36.

40 See, e.g., Lujan v. Defs. of Wildlife, 504 U.S. 555, 560-61 (1992).

41 Id. at 560 (footnote and citations omitted) (quoting Whitmore v. Arkansas, 495 U.S. 149, 155 (1990)).

${ }^{42}$ Id. at $560-61$.

43 Id. at 561 (quoting Simon v. E. Ky. Welfare Rights Org., 426 U.S. 26, 38, 43 (1976)).

44 Jonathan Remy Nash, Standing's Expected Value, 111 Mich. L. REV. 1283, 1304 (2013); see supra note 1 and accompanying text.

45 See Woolhandler \& Collins, supra note 29.

46 See id. at 406-34.

47 Emphasizing the importance of historical context in interpreting some cases as well as the frequency of boundary dispute cases in the Court's original jurisdiction, Professor Shannon Roesler reads the early cases not to present the same degree of hostility to sovereign-based state standing that Professors Woolhandler and Collins suggest. See Roesler, supra note 33, at 644-49.
} 
courts were more likely to find standing where an intergovernmental lawsuit bore resemblance to a traditional suit at common law.

The early years of the twentieth century saw the Court begin to loosen slightly the barrier against states litigating sovereign interests in federal court ${ }^{48}$ such that "the Court no longer necessarily relied on the common law to decide the merits of intergovernmental disputes." 49 Highlighted by a string of state "public nuisance" cases ${ }^{50}$ brought before the Supreme Court in the early twentieth century, ${ }^{51}$ the Court opened the door slightly to allowing states to seek to vindicate their quasi-sovereign-sometimes called parens patriae-interests. ${ }^{52}$

Exactly what constitutes a quasi-sovereign interest remains murky. The clearest exposition of the scope of quasi-sovereignty came in the 1982 case of Alfred L. Snapp \& Son, Inc. v. Puerto Rico ex rel. Barez..53 There, Puerto Rico (which, the Court stated, was "similarly situated" to a state in terms of its ability to rely on quasi-sovereign interests to invoke federal court jurisdiction ${ }^{54}$ ) sought to invoke its parens patriae rights on behalf of its citizens, arguing that apple growers in Virginia had failed to comply with federal law that required employers to give hiring preference to Puerto Ricans over temporary foreign workers..$^{55}$ The Court took the opportunity to enumerate the various types of interests on which states might rely to establish federal court standing. First, "sovereign interests" include (1) "the exercise of sovereign power over individuals and entities within the relevant jurisdiction," which "involves the power to create and enforce a legal code, both civil and criminal"; and (2) "the demand for recognition from other sovereigns," which "most frequently... involves the maintenance and recognition of borders." ${ }^{6}$ Second, a state may advance nonsovereign "proprietary interests" and "private interests." 57 In this

\footnotetext{
48 See Woolhandler \& Collins, supra note 29, at 446-64.

49 Id. at 455.

${ }^{50}$ In a public nuisance case, a state seeks to vindicate public interests by enjoining a public nuisance on the grounds of harms to its citizens' health, safety, and economic welfare. See id. at 411.

51 See, e.g., Georgia v. Tenn. Copper Co., 206 U.S. 230 (1907); Missouri v. Illinois, 200 U.S. 496 (1906); Missouri v. Illinois, 180 U.S. 208 (1901).

52 See, e.g., Tenn. Copper, 206 U.S. at 237 ("This is a suit by a State for an injury to it in its capacity of quasi-sovereign. In that capacity the State has an interest independent of and behind the titles of its citizens, in all the earth and air within its domain.").

53458 U.S. 592 (1982).

54 Id. at 608 n.15 ("[T]he Commonwealth of Puerto Rico is similarly situated to a State in this respect: It has a claim to represent its quasi-sovereign interests in federal court at least as strong as that of any State.”).

55 See id. at 594-96.

$56 I d$. at 601.

${ }^{57} \mathrm{Id}$. at 601-02.
} 
capacity, the state sues much as would a typical nonsovereign litigant (along the lines of Professors Woolhandler and Collins' historical finding of ample actions by states based on the common law). ${ }^{58}$

The Alfred L. Snapp Court then turned its attention to quasi-sovereign interests, which "consist of a set of interests that the State has in the wellbeing of its populace." ${ }^{59}$ In order to maintain an action based on a quasisovereign interest, "the State must articulate an interest apart from the interests of particular private parties, i.e., the State must be more than a nominal party. The State must express a quasi-sovereign interest." 60 The Court then identified two "general categories" of cases into which successful quasi-sovereign cases (thus far) had fallen: (1) cases where "a State has a quasi-sovereign interest in the health and well-being-both physical and economic - of its residents in general"; and (2) cases where "a State has a quasi-sovereign interest in not being discriminatorily denied its rightful status within the federal system." ${ }^{61}$ Although the Court did not consider whether there might be additional categories of quasi-sovereign interests, it reaffirmed its earlier cases recognizing that states can invoke the protection of the federal courts on the basis of quasi-sovereign interests. Thus, by the modern era, the Court had recognized that states had a right to sue for common law injuries, sovereign interests, and a few categories of quasi-sovereign interests.

\section{The Supreme Court and State Standing to Sue the Federal Government}

I turn now to the narrower topic that is the focus of my analysis: the standing of states to sue the federal government (as opposed to any other defendant). I address the issue in the context of three time periods - the nineteenth century, the first half of the twentieth century, and recent years. I canvas three types of injuries that plaintiff states have asserted-injury to sovereignty interests, direct injury, and injury to quasi-sovereignty interests - and the extent to which the Court accepted those injuries as a

\footnotetext{
58 The Court explained:

Two kinds of nonsovereign interests are to be distinguished. First, like other associations and private parties, a State is bound to have a variety of proprietary interests. A State may, for example, own land or participate in a business venture. As a proprietor, it is likely to have the same interests as other similarly situated proprietors. And like other such proprietors it may at times need to pursue those interests in court. Second, a State may, for a variety of reasons, attempt to pursue the interests of a private party, and pursue those interests only for the sake of the real party in interest. Interests of private parties are obviously not in themselves sovereign interests, and they do not become such simply by virtue of the State's aiding in their achievement. In such situations, the State is no more than a nominal party.

${ }^{60} I d$. at 607.

${ }^{61} \mathrm{Id}$.
} 
basis for standing. While the Court initially disfavored suits by states against the federal government as a general matter and continued to view injuries to sovereign interests with suspicion, it eventually recognized standing based on allegation of direct injuries. Its evaluation of injuries to state quasi-sovereignty interests as a basis for standing to sue the federal government remains murky.

\section{Nineteenth Century}

Historically, the Supreme Court disfavored suits by states against the federal government. Two early original jurisdiction cases arose out of efforts by Southern states to put a halt to Reconstruction. In the first, Mississippi v. Johnson, the Court (though it ultimately declined to hear the case on the merits) seemed open to the idea that "in some cases ... such a bill may be filed against the United States." ${ }^{2}$ In the other case-Georgia $v$. Stanton $^{63}$ - the Court's rejection of the State's standing seemed more absolute. Citing cases where states had filed suit as plaintiffs (but not against a federal government actor), and harkening back to the notion that only actions grounded in common law were generally allowed to move forward, the Court emphasized that the complaint called "for the judgment of the court upon political questions, and, upon rights not of persons or property, but of a political character." ${ }^{64}$ In short, whatever the reason, the Court was reluctant to recognize state standing to sue the federal government in this era.

\section{The Early Twentieth Century}

The first part of the twentieth century was a time of transition in standing law. ${ }^{65}$ Simplifying the history here for purposes of a concise narrative, legal initiatives by progressive interest groups and lawyers sought to establish regulation of economic transactions in order to expand

6271 U.S. 475, 501 (1866) ("It is true that a State may file an original bill in this court. And it may be true, in some cases, that such a bill may be filed against the United States. But we are fully satisfied that this court has no jurisdiction of a bill to enjoin the President in the performance of his official duties; and that no such bill ought to be received by us.").

6373 U.S. 50 (1867).

${ }^{64}$ Id. at 77. The Court stated:

That these matters, both as stated in the body of the bill, and, in the prayers for relief, call for the judgment of the court upon political questions, and, upon rights not of persons or property, but of a political character, will hardly be denied. For the rights for the protection of which our authority is invoked, are the rights of sovereignty, of political jurisdiction, of government, of corporate existence as a State, with all its constitutional powers and privileges. No case of private rights or private property infringed, or in danger of actual or threatened infringement, is presented by the bill, in a judicial form, for the judgment of the court.

Id.

65 See Woolhandler \& Collins, supra note 29, at 469 ("This era for standing therefore was more transitional than is usually supposed ...."). 
personal liberties and rights. In turn, this prompted evolution in the law of federal court standing. ${ }^{66}$ Perhaps recognizing the likely growth of lawsuits advancing personal rights and liberties, the Court sought to cull that growth by developing more specific, and restrictive, standards for litigant standing: As lawsuits began to move away from their common law moorings, the Court responded by starting to develop the modern test for standing. In many senses, that test seeks to ensure that lawsuits have at least a substantial resemblance to suits at common law by emphasizing the importance of economic injury caused by the defendant. ${ }^{67}$ Still, the Court designed its approach to stem, not to stop, the tide of cases alleging categories of injuries not previously welcomed in the courts.

Like other litigants, states sought to take advantage of the Court's growing openness to recognize injuries not typically seen at common law. One can see in the Supreme Court's cases three types of injuries advanced by states: (1) truly sovereign interests (like those advanced by the Southern states challenging Reconstruction); (2) direct interests (like those advanced in boundary cases); and (3) quasi-sovereign (or parens patriae) interests. Indeed, much like (as described in the Introduction) Texas tried to frame its injury in its recent immigration challenge in multiple ways, the states sometimes raised more than one type of interest in a case (with varying degrees of success). ${ }^{68}$ The following Sections address the Court's treatment of each type of interest in turn. ${ }^{69}$

\footnotetext{
${ }^{66}$ Beyond the realm of the law of standing, the Court generally clung to the notion that the Due Process Clause protects economic, but not personal, rights and liberties. See, e.g., James E. Fleming, Fidelity, Basic Liberties, and the Specter of Lochner, 41 WM. \& MARY L. REV. 147, 149 (1999).

67 See Woolhandler \& Collins, supra note 29, at 466-69.

${ }^{68}$ See, e.g., id. at $491 \mathrm{n} .420$ (noting that the Florida v. Mellon Court "attempt[ed] to maintain a line between direct and indirect injuries") (citing 273 U.S. 12, 18 (1927)). The assertion of various types of injuries makes it important to keep track of which type of injury the Court is addressing at which point. For example, while Professor Vladeck correctly notes that Texas v. Interstate Commerce Commission, 258 U.S. 158 (1922), saw a state raise a standing argument "comparable" to the one raised in Massachusetts v. Mellon, Vladeck, supra note 29, at 852-53, the State based that comparable claim on its sovereign interest, not the quasi-sovereign argument for which Massachusetts $v$. Mellon is widely known. See infra text accompanying notes 71-74.

${ }^{69}$ Insofar as states often tried to frame their injuries so as to resemble multiple paradigmatic interests, a single case sometimes appears in more than one Section. Some commentators have argued that the restrictions on standing we observe in many of the Supreme Court cases I survey are actually a feature not of Article III standing but of equitable considerations that attend the invocation of the Supreme Court's original jurisdiction. See, e.g., Grove, supra note 4, at 868-69 ("[T] he Court's original cases do not undermine state standing to assert such interests in federal district court, or on appeal to the Supreme Court."); Roesler, supra note 33, at 650,654; Woolhandler \& Collins, supra note 29, at 489 (footnote omitted) ("Over time, the Court developed certain principles to exclude cases from its original jurisdiction, even though that jurisdiction theoretically could be invoked as a matter of right. Some of these principles prohibit state-as-plaintiff litigation of certain claims altogether, whereas others allow states to sue in lower courts."); infra note 82 (noting a statement to this effect by the Supreme Court).
} 


\section{a. Injury to sovereign interests}

The Court treated arguments that a state's truly sovereign intereststhat is, its ability to enact and enforce its own laws-gave rise to federal court standing the same way that it had a half century earlier in the Reconstruction cases: The Court declined to proceed, describing the claims as nonjusticiable political questions. ${ }^{70}$

In the 1922 case of Texas $v$. Interstate Commerce Commission, ${ }^{71}$ the State sought to challenge provisions of the Transportation Act of 1920 on the ground that Congress exceeded its constitutional authority in enacting them. The Court rejected Texas's assertion of its sovereign interests as the basis for standing. ${ }^{72}$ The argument by the State in the 1923 case of Massachusetts $v$. Mellon ${ }^{73}$ - raising a challenge to a federal statute (the Sheppard-Towner (Maternity) Act of 1921) that tied federal funding to state spending to reduce infant and maternal mortality - met a similar fate. ${ }^{74}$ Likewise, in the 1926 case of New Jersey $v$. Sargent,$^{75}$ the Court again rejected the State's sovereignty-based standing arguments. Here the State unsuccessfully argued that Congress had exceeded its constitutional authority and improperly invaded the province of the State in enacting

The precise distinctions between the boundaries of Article III standing and Supreme Court original jurisdiction equitable standing nevertheless remain unclear. See, e.g., Woolhandler \& Collins, supra note 29, at 490-91 ("Although the Court first articulated th[e] principle"- that a state cannot assert parens patriae standing to protect its citizens from the operation of an allegedly unconstitutional federal statute - "in an original jurisdiction suit, the principle bars state standing in the lower federal courts as well as in the Supreme Court."). But the precise distinctions are not integral to my argument. As the text below shows, even taking the Court's statements about standing as describing the Article III boundaries, the Court accepted standing where states relied on quasi-sovereign injuries allegedly caused by the federal government, see infra Section I.C.2.c, and that position is consistent with the argument I advance in favor of sovereign preemption state standing. Thus, my exposition simply takes the Court's statements about standing at face value.

70 See supra Section I.C.1.

71258 U.S. 158 (1922).

72 The Court explained:

[T]his part of the bill does not present a case or controversy within the range of the judicial power as defined by the Constitution. It is only where rights, in themselves appropriate subjects of judicial cognizance, are being, or about to be, affected prejudicially by the application or enforcement of a statute that its validity may be called in question by a suitor and determined by an exertion of the judicial power.

Id. at 162 .

73262 U.S. 447 (1923).

74 The Court stated:

[T] he complaint of the plaintiff State is brought to the naked contention that Congress has usurped the reserved powers of the several States by the mere enactment of the statute, though nothing has been done and nothing is to be done without their consent; and it is plain that that question, as it is thus presented, is political, and not judicial, in character, and therefore is not a matter which admits of the exercise of the judicial power.

Id. at 483 .

75269 U.S. 328 (1926). 
certain provisions of the Federal Water Power Act and applying them to waters within and bordering the State. ${ }^{76}$

In short, the early twentieth century Court remained hostile to state suits against the federal government based on alleged injuries to the state's sovereignty.

\section{b. Direct injury}

A direct injury is an injury that sovereigns and nonsovereigns can suffer alike. In the early twentieth century, the Court confronted settings where states alleged injury under a specific federal statute or injury resulting from agency action under some federal statute. The Court generally applied the same standing requirements that it would have applied in a case involving a plaintiff without sovereign status. Indeed, one can see glimpses of elements that would later become part of the modern tripartite standing test. Moreover, the Court did not uniformly deny the state's ability to proceed, although it sometimes directed the state to seek relief in a lower federal court (or approved standing where the state had initiated proceedings in the lower federal court).

The Court's 1920 decision in Missouri v. Holland provides an early example. ${ }^{77}$ There, the State of Missouri filed suit in a lower federal court. Naming a federal game warden as defendant, the State sought to bar enforcement of a treaty between the U.S. and Great Britain governing migratory birds, as well as regulations promulgated by the Department of Agriculture pursuant to the treaty. ${ }^{78}$ In upholding the State's standing, the Court noted that " $[\mathrm{t}]$ he State ... alleges a pecuniary interest, as owner of the wild birds within its borders and otherwise, admitted by the Government to be sufficient ...." 79

Texas v. Interstate Commerce Commission provides another example. As noted above, Texas advanced an injury to its truly sovereign interests by virtue of the allegedly unconstitutional enactment of the Transportation Act

\footnotetext{
76 The Court explained:

The defendants respond with a motion to dismiss, on the grounds, among others, that the bill does not present a case or controversy appropriate for the exertion of judicial power but only an abstract question respecting the relative authority of Congress and the State in dealing with such waters. If this be a proper characterization of the bill the motion to dismiss must prevail, as a reference to prior decisions will show.

Id. at 330. And, indeed, the Court proceeded to survey earlier authorities-including Georgia $v$. Stanton, Texas v. Interstate Commerce Commission, and Massachusetts v. Mellon, where the Court had concluded that the questions raised were not justiciable. See id. at 330-34.

77252 U.S. 416 (1920).

78 Id. at 430-31.

79 Id. at 431.
} 
of $1920 .{ }^{80}$ But Texas also challenged the validity of particular orders of the Interstate Commerce Commission under that Act. ${ }^{81}$ In response to that claim, the Court found that the State could seek relief but only by joining interstate carriers affected by the orders and filing "a suit in the District Court in which the United States is made a party." 82

In its 1927 decision in Florida v. Mellon, ${ }^{83}$ the Court confronted Florida's challenge to a federal inheritance tax law. Florida alleged "that the state is directly injured because the imposition of the federal tax, in the absence of a state tax which may be credited, will cause the withdrawal of property from the state with the consequent loss to the state of subjects of taxation." "84 The Court found this allegation insufficient to support the State's right to pursue its suit since-using language that would decades later become a familiar part of the modern test for standing - the notion that people would withdraw property from the State as a result of the federal statute was "purely speculative, and, at most, only remote and indirect." 85 Thus, the Court's decision emphasized-in terms common to current standing analysis - that the case before it did not present a sufficient injury. However, the Court did not preclude the possibility that a state could allege a valid direct injury against the federal government.

In sum, the early-twentieth-century Court recognized that states could establish standing to sue the federal government based on an adequate direct injury.

\section{c. Injury to quasi-sovereign interests}

A state relies on a quasi-sovereign interest when it seeks to vindicate the well-being of its populace. ${ }^{86}$ As we shall see, courts of the era drew a distinction between cases where states relied on what we might call "competing parens patriae interests" on the one hand and cases where states relied on what we might call "true quasi-sovereign interests" on the other. Competing parens patriae interests are generic interests the state has in preserving its right to regulate in the face of allegedly illegal lawmaking by the federal government (or a federal government actor). The state simply

\footnotetext{
${ }^{80}$ See supra text accompanying notes 71-72.

81 See Texas v. Interstate Commerce Comm'n \& R.R. Labor Bd., 258 U.S. 158, 163-64 (1922).

82 Id. at 164; see North Dakota ex rel. Lemke v. Chicago, 257 U.S. 485, 491 (1922) ("There is no doubt that a State can sue in the District Court when the United States is a party and has consented to be sued there and has not expressed its consent to be sued elsewhere.").

83273 U.S. 12 (1927).

${ }^{84} \mathrm{Id}$. at 16

85 Id. at 18

86 See Alfred L. Snapp \& Son, Inc. v. Puerto Rico ex rel. Barez, 458 U.S. 592, 602 (1982) ("Quasisovereign interests . . consist of a set of interests that the State has in the well-being of its populace.").
} 
asserts that its claim to legislate in its parens patriae capacity trumps the federal government's competing parens patriae claim. The Court routinely rejected standing based on such allegations.

In contrast, true quasi-sovereign interests are interests the state has in retaining jurisdiction to exercise its police power-perhaps especially, during this time period, over natural resources-within its borders in the face of federal government attempts to divest it of that jurisdiction. Thus, true quasi-sovereign interests differ from competing parens patriae interests in that a state asserting the former argues that the federal government has wrongly divested it of specific police power authority, leaving it unable to act within its borders to protect its citizenry. The Court in this era recognized standing based on allegations of infringement of a state's true quasi-sovereign interests.

Consider first cases of competing parens patriae interests. Massachusetts $v$. Mellon (discussed above in the context of the sovereign injury raised in the case) today represents the keystone in the line of precedent disapproving of injury to quasi-sovereign interests as a basis for state standing to sue the federal government. ${ }^{87}$ The Court in Massachusetts v. Mellon rejected the State's assertion that it had parens patriae standing to challenge the federal Sheppard-Towner Act's requirement that federal funding match state expenditures:

We... consider whether the suit may be maintained by the State as the representative of its citizens. To this the answer is not doubtful. We need not go so far as to say that a State may never intervene by suit to protect its citizens against any form of enforcement of unconstitutional acts of Congress; but we are clear that the right to do so does not arise here. Ordinarily, at least, the only way in which a State may afford protection to its citizens in such cases is through the enforcement of its own criminal statutes, where that is appropriate, or by opening its courts to the injured persons for the maintenance of civil suits or actions. But the citizens of Massachusetts are also citizens of the United States. It cannot be conceded that a State, as parens patriae, may institute judicial proceedings to protect citizens of the United States from the operation of the statutes thereof. While the State, under some circumstances, may sue in that capacity for the protection of its citizens, it is no part of its duty or power to enforce their rights in respect of their relations with the Federal Government. In that field it is the United States, and not the State, which represents them as parens patriae, when such representation

\footnotetext{
87 See, e.g., Vladeck, supra note 29, at 851 ("The fountainhead case in this field is the Supreme Court's ... decision in Massachusetts v. Mellon.").
} 
becomes appropriate; and to the former, and not to the latter, they must look for such protective measures as flow from that status. ${ }^{88}$

Because the United States had a legitimate parens patriae interest, and such an interest displaces a state's parens patriae interest, Massachusetts had no injury and, therefore, no standing to sue.

In Florida v. Mellon (discussed above in the context of the direct injury raised by the State), the State argued that, by virtue of the introduction of the federal inheritance tax, "the citizens of the state are injured in such a way that the state may sue in their behalf as parens patriae." ${ }^{89}$ The Court summarily dismissed this injury as a basis for suit, relying heavily on its earlier opinion in Massachusetts $v$. Mellon..$^{90}$

Contrast these cases raising "competing parens patriae" injuries, where the Court proved unwilling to find state standing, with cases raising "true quasi-sovereign" injuries, where the Court did recognize standing. In Missouri v. Holland (discussed above in the context of the direct injury raised), the State filed a claim challenging enforcement of the migratory bird treaty with Great Britain, as well as of a statute passed to give effect to the treaty and of Department of Agriculture regulations promulgated pursuant to the treaty. ${ }^{91}$ Missouri argued the federal actions would "invade the sovereign right of the State and contravene its will manifested in statutes." 92 Or, as the State put it, federal law "[invades] the sovereign right and power ... to control and regulate the taking, killing and use of wild game within its borders." ${ }_{93}$ After noting the government's concession that the State's direct injury (by virtue of its proprietary interest in wild birds within its borders) gave rise to standing, ${ }^{94}$ the Court stated: "[I]t is enough that the bill is a reasonable and proper means to assert the alleged quasi sovereign rights of a State." ${ }_{95}$ While the Court's opinion in this regard is not a model of clarity, it seems that the Court rested its conclusion on the State's quasi-sovereign rights in the natural resource of migratory birds

\footnotetext{
88262 U.S. 447, 485-86 (1923) (citation omitted).

89273 U.S. at 16.

90 The entirety of the Court's reasoning is as follows: Nor can the suit be maintained by the state because of any injury to its citizens. They are also citizens of the United States and subject to its laws. In respect of their relations with the federal government, "it is the United States, and not the State, which represents them as parens patriae, when such representation becomes appropriate; and to the former, and not to the latter, they must look for such protective measures as flow from that status." $I d$. at 18 (quoting Mellon, 262 U.S. at 486).

91252 U.S. 416, 431-32 (1920).

92 Id. at 431.

93 Motion to Advance at 3, Missouri v. Holland, 252 U.S. 416 (1920) (No. 609).

94 Missouri, 252 U.S. at 431; see also supra notes 78-79 and accompanying text.

${ }^{95}$ Missouri, 252 U.S. at 431.
} 
within its borders, ${ }^{96}$ a point bolstered by the Court's citation of several earlier cases affirming state standing to assert rights in regulating natural resources. ${ }^{97}$

In a 1925 case, Colorado v. Toll, ${ }^{98}$ the State also asserted a true quasisovereign interest. The case emerged in the wake of the creation of the Rocky Mountain National Park. The park included areas currently inhabited ${ }^{99}$ and had "roads . . . built by counties and the State . . before the park was laid out." ${ }^{100}$ Colorado alleged that it never had ceded sovereignty over the park. ${ }^{101}$ The dispute in Toll arose when the defendant - the park superintendent-asserted the authority (allegedly in violation of the governing federal statute) to ban anyone from residing permanently in the park and to preclude any for-hire automobiles on the roads within the park except those to which he had granted licenses. ${ }^{102}$ The Court explained that "[t]he object of the bill is to restrain an individual from doing acts that it is alleged that he has no authority to do and that derogate from the quasisovereign authority of the State." ${ }_{103}$ Citing Missouri v. Holland, the Court upheld jurisdiction, reversing the contrary judgment of the district court. ${ }^{104}$ While once again the Court did not elucidate the nature of the quasisovereign rights in question as clearly as it could have, it seems fairly clear

96 Professor Grove argues that Justice Holmes's reference in Missouri v. Holland to "quasi sovereign rights" pertained more to preemption of state law than to the State's right to protect and regulate its natural resources:

Today, jurists and scholars often associate [quasi sovereign rights] with parens patriae standing, the authority of a State to bring suit on behalf of private citizens, largely because that is how the Supreme Court used the term in [Alfred L. Snapp \& Son, Inc. v. Puerto Rico ex rel. Barez, 458 U.S. 592, 602 (1982)]. But Justice Holmes was using the term "quasi-sovereign" in a very different sense - to refer to the State's sovereign interest in the continued enforceability of state law.

Grove, supra note 4, at 865 (citations omitted). But this argument ignores both the fact that the subject of regulation here was clearly a natural resource and that Justice Holmes's opinion immediately after referring to "quasi sovereign rights" cited to other cases where a state had sought to vindicate its right to preserve and regulate its natural resources. See infra note 97; see also Massachusetts v. Mellon, 262 U.S. 447, at 482 (1923) (describing the Court as having found standing in Missouri v. Holland "because, as asserted, there was an invasion, by acts done and threatened, of the quasi sovereign right of the state to regulate the taking of wild game within its borders")

97252 U.S. at 431 (citing Kansas v. Colorado, 185 U.S. 125, 142 (1902); Georgia v. Tenn. Copper Co., 206 U.S. 230, 237 (1907); Marshall Dental Mfg. Co. v. Iowa, 226 U.S. 460, 462 (1913)).

98268 U.S. 228 (1925).

99 See id. at 229 ("There are many thousands of acres in the park owned by private persons, and there are houses and hotels that were built before the park was laid out.").
$100 I d$. at 230.
$101 \mathrm{Id}$.
102 Id. at 229.
103 Id. at 230 .
$104 \mathrm{Id}$. 
that the State complained of losing the power to regulate territory within its borders as to which it had never ceded sovereignty.

Thus, in the early twentieth century, the Court recognized two bases for state standing to sue the federal government: direct injuries and an emerging concept of quasi-sovereign rights.

\section{The Modern Era}

In the modern era, the Supreme Court has developed and refined the generally applicable test for standing with which we are familiar today. But on a few occasions, the Court focused on, and recognized, the standing of states to challenge the action of the federal government. Most of these cases involve direct injuries to the states. However, the basis for the Court's conclusion that standing existed in one case (perhaps the leading modern case)-Massachusetts $v$. EPA ${ }^{105}$ - is less than clear. I canvass the direct-injury cases and then turn to the Court's garbled holding in Massachusetts v. EPA.

\section{a. Direct-injury cases}

In a series of cases, the Court has recognized the standing of states based on constitutional injuries actually suffered by the states. While one might seek alternatively to categorize these injuries as sovereign in nature because the Constitution vests the underlying rights in the states as sovereigns, these injuries are better understood, as I discuss below, as direct injuries since the rights allegedly infringed belong to the states themselves. ${ }^{106}$

In 1966, the Court decided South Carolina v. Katzenbach, upholding provisions of the Voting Rights Act of 1965 against challenges by several States. ${ }^{107}$ The ground for the States' challenges - that the provisions of the Act "exceed[ed] the powers of Congress and encroach[ed] on an area reserved to the States by the Constitution" 108 _ sounds like one the Court would have dismissed as a nonjusticiable sovereign injury under the reasoning of Georgia v. Stanton and its progeny. ${ }^{109}$ But the Court proceeded to consider on the merits the States' argument that Congress could not set voter qualifications in state and federal elections under the Fifteenth Amendment. While the Court did not make clear the basis for the States'

105549 U.S. 497 (2007)

106 See infra text accompanying notes 126-28.

107383 U.S. 301, 308 (1966).

108 Id. at 323.

109 See supra note 63 and accompanying text. 
standing, ${ }^{110}$ commentators believe the States had standing to advance this claim because "the state sought to litigate its own liberty interest in setting voter qualifications, as provided by specific provisions of the Constitution that expressly contemplate state power to set such qualifications." 111 Bolstering this conclusion is the fact that the Court did conclude that the States lacked standing in respect of other claims they tried to advance. ${ }^{112}$

Four years later, in Oregon v. Mitchell, the Court considered the merits of arguments by four States against federal legislation requiring them to implement the eighteen-year-old voting age. ${ }^{113}$ The Court noted that "[n]o question has been raised concerning the standing of the parties or the jurisdiction of this Court," and raised no question of its own. ${ }^{114}$ As in Katzenbach, "[t]he Court again based the state's standing on explicit constitutional language contemplating general state control of election qualifications." 115

South Carolina v. Regan, decided in 1984, involved a challenge by the State to a change to the federal tax law that retained the exemption from federal income taxation for interest earned on state-issued bonds, but only for certain types of bonds. ${ }^{116}$ The State argued that the tax law change violated the State's rights under the Tenth Amendment. ${ }^{117}$ The Court accepted without discussion the standing of the plaintiff State. However, the Court's reasoning, in the course of rejecting the applicability of the Tax Anti-Injunction Act (TAIA) ${ }^{118}$ to bar the State's suit, confirms the fact that

110 See Katzenbach, 383 U.S. at 324 ("[A] State [does not] have standing as the parent of its citizens to invoke these constitutional provisions against the Federal Government, the ultimate parens patriae of every American citizen. The objections to the Act which are raised under these provisions may therefore be considered only as additional aspects of the basic question presented by the case: Has Congress exercised its powers under the Fifteenth Amendment in an appropriate manner with relation to the States?" (citations omitted)).

111 Woolhandler \& Collins, supra note 29, at 492.

112 The Katzenbach Court explained:

The word "person" in the context of the Due Process Clause of the Fifth Amendment cannot ... be expanded to encompass the States of the Union, and to our knowledge this has never been done by any court. Likewise, courts have consistently regarded the Bill of Attainder Clause of Article I and the principle of separation of powers only as protections for individual persons and private groups, those who are peculiarly vulnerable to non-judicial determinations of guilt. Nor does a State have standing as the parent of its citizens to invoke these constitutional provisions against the Federal Government, the ultimate parens patriae of every American citizen.

383 U.S. at 323-24 (citations omitted). For further discussion, see Woolhandler \& Collins, supra note 29 , at $492-93$.

113400 U.S. 112, 117 (1970).

114 Id. at 117 n. 1 .

115 Woolhandler \& Collins, supra note 29, at 493.

116465 U.S. 367, 371-72 (1984).

117 Id. at 370.

11826 U.S.C. § 7421(a) (2012). 
the Constitution assigned the right at issue directly to the State. The federal government argued that, while the Court had interpreted the TAIA to be inapplicable where the would-be plaintiff had no alternative remedy, here the State did have an alternative remedy: It could rely on a lawsuit by a bondholder to challenge the change to the federal tax law. ${ }^{119}$ In rejecting this argument, the Court noted that "instances in which a third party may raise the constitutional rights of another are the exception rather than the rule." 120 This statement affirms that the constitutional rights at issue in the case belonged uniquely to the State.

In two more cases after Regan (both of which commenced in federal district court ${ }^{121}$ ), the Court recognized state standing without addressing the issue. But in both cases, the constitutional rights advanced by the plaintiff States clearly belonged uniquely to the States. In South Dakota v. Dole, the Court upheld a federal provision that hinged state receipt of federal highway funds on the State's agreement to set the minimum drinking age at twenty-one. ${ }^{122}$ South Dakota argued that the federal statute infringed rights accorded directly to it (the State) under the Twenty-First Amendment. ${ }^{123}$ And, in New York v. United States, ${ }^{124}$ New York raised a challenge - resting on its rights under the Tenth Amendment and the Constitution's Guarantee Clause ${ }^{125}$ - to a federal law that required the State either to take title to radioactive waste or to regulate it on Congress's terms. Again, in both cases it was clear that the rights the plaintiff States asserted belonged uniquely to the States themselves.

While one might justifiably say that the States in these cases are raising sovereign injuries (in that the Constitution vests all the rights in question in state sovereigns) or quasi-sovereign injuries (in that the states

\footnotetext{
119 Regan, 465 U.S. at 380.

${ }^{120} \mathrm{Id}$.

121 See supra note 69 (discussing the Supreme Court's original jurisdiction over suits brought by plaintiff states).

122483 U.S. 203, 212 (1987).

${ }^{123}$ Id. at 205. Section 2 of the Twenty-First Amendment to the Constitution provides: "The transportation or importation into any State, Territory, or possession of the United States for delivery or use therein of intoxicating liquors, in violation of the laws thereof, is hereby prohibited." U.S. CONST. amend. XXI, § 2. The State pointed to Supreme Court precedent holding that "the "Twenty-first Amendment grants the States virtually complete control over whether to permit importation or sale of liquor and how to structure the liquor distribution system." Dole, 483 U.S. 203, 205 (1987) (quoting Cal. Retail Liquor Dealers Ass'n v. Midcal Aluminum, Inc., 445 U.S. 97, 110 (1980)).

124505 U.S. 144, 149-54 (1992).

125 The Constitution's Guarantee Clause provides: "The United States shall guarantee to every State in this Union a Republican Form of Government, and shall protect each of them against Invasion; and on Application of the Legislature, or of the Executive (when the Legislature cannot be convened) against domestic Violence." U.S. CONST. art. IV, § 4.
} 
are really raising their arguments on behalf of their citizenry), ${ }^{126}$ it seems far more apt to say that the States here are raising direct injuries. ${ }^{127}$ While direct-injury cases in the nineteenth century extended typically to property and contract rights, in the cases just discussed, the State is suing to protect its own (now constitutional) rights, just as a private actor might sue to protect his or her own rights. ${ }^{128}$

\section{b. A Case that Defies Classification: Massachusetts v. EPA}

In the most recent case where the Court addressed, and upheld, state standing, the Court's language leaves unclear the precise nature of the state injury that justified standing. In Massachusetts v. EPA, ${ }^{129}$ the Court reviewed the denial by the U.S. Environmental Protection Agency of a petition requesting that the agency regulate greenhouse gas emissions from motor vehicles. ${ }^{130}$ Although numerous parties aligned against the EPA, ${ }^{131}$ the Court rested its analysis of standing on the injury to the State of Massachusetts. ${ }^{132}$

While the Court's opinion clearly concludes that Massachusetts had standing, the majority opinion does not clearly identify the precise nature of the relevant injury. Instead the Court seems to vacillate between characterizing the State's injury as quasi-sovereign and as direct. On the one hand, the Court recited the traditional test for standing ${ }^{133}$ and ultimately identified the injury as Massachusetts's loss of coastline on its sovereign lands, ${ }^{134}$ a "garden-variety harm that would typically satisfy standing requirements." ${ }^{135}$ In addition, the Court explained how the EPA did not

\footnotetext{
126 See Alexander M. Bickel, The Voting Rights Cases, 1966 SuP. CT. REV. 79, 86-90 (criticizing the Court's holding on standing in Katzenbach as inconsistent with its holding in Massachusetts $v$. Mellon); Henry P. Monaghan, Constitutional Adjudication: The Who and When, 82 YALE L.J. 1363, 1382 (1973) ("Since no pretense can be made that these cases involve 'private' rights, Professor Bickel is clearly correct in concluding that they stand in open contradiction to the Reconstruction cases and Massachusetts v. Mellon.”).

127 See Vladeck, supra note 29, at 857-65; Woolhandler \& Collins, supra note 29, at 492-94.

128 See Woolhandler \& Collins, supra note 29, at 493. It is on this basis that Professor Vladeck argues that, while Professor Bickel correctly urged the retention of Massachusetts v. Mellon as good law on the ground that "preemption of a state's law by the contested federal law cannot of itself provide the basis for state standing against the federal government," the very same "thesis would suggest that, Bickel's objections notwithstanding, the Supreme Court's decision in [Katzenbach] was also correct." Vladeck, supra note 29 , at 849.

129549 U.S. 497 (2007).

130 See id. at $510-16$.

131 The original petition was filed by nineteen private organizations. Id. at $510 \&$ n. 15 .

132 Id. at 518. The Court reasoned that "[o]nly one of the petitioners needs to have standing to permit us to consider the petition for review." Id.

133 See id. at 517-18.

134 Id. at 519.

135 Nash, supra note 44, at 1294.
} 
contest the harm caused by greenhouse gas emissions, thus allowing the Court to depict the harm as not merely conjectural136 - again, a logical maneuver one might expect in a typical standing analysis.

On the other hand, immediately after reciting the traditional test for standing, the Court asserted that "[i]t is of considerable relevance that the party seeking review here is a sovereign State and not... a private individual." 137 The Court then invoked its opinion in Georgia v. Tennessee Copper Co. ${ }^{138}$ one of the quasi-sovereignty cases from the early twentieth century. There, the Court upheld Georgia's standing - to sue a private actor, not the federal government-based on an assertion of Georgia's quasi-sovereign interests in order to vindicate the health of its citizenry in the face of heavy pollution from beyond its borders. ${ }^{139}$ The Court then launched into a description of how Massachusetts's inability to protect its citizens against climate change - by virtue of having "surrender[ed] sovereign prerogatives" to the federal government - gave rise to an injury where the federal government, though directed to address the problem, refused to act:

When a State enters the Union, it surrenders certain sovereign prerogatives. Massachusetts cannot invade Rhode Island to force reductions in greenhouse gas emissions, it cannot negotiate an emissions treaty with China or India, and in some circumstances the exercise of its police powers to reduce in-state motor-vehicle emissions might well be pre-empted.

These sovereign prerogatives are now lodged in the Federal Government, and Congress has ordered EPA to protect Massachusetts (among others) by prescribing standards applicable to the "emission of any air pollutant from any class or classes of new motor vehicle engines, which in [the Administrator's] judgment cause, or contribute to, air pollution which may reasonably be anticipated to endanger public health or welfare." Congress has moreover recognized a concomitant procedural right to challenge the rejection of its rulemaking petition as arbitrary and capricious. Given that procedural right and Massachusetts' stake in protecting its quasi-sovereign interests, the Commonwealth is entitled to special solicitude in our standing analysis. ${ }^{140}$

Reconciling the Court's divergent descriptions of the State's injury presents no small challenge. While the Massachusetts Court said states are due "special solicitude" in the standing calculus, one is left to wonder what

\footnotetext{
136 Massachusetts, 549 U.S. at 521.

137 Id. at 518.

138 Id. at 518-19 (citing Georgia v. Tenn. Copper Co., 206 U.S. 230, 237 (1907)).

139 See Tenn. Copper Co., 206 U.S. at 237.

140 Massachusetts, 549 U.S. at 519-20 (alteration in original) (citations omitted) (quoting 42 U.S.C. § 7521(a)(1) (2012)).
} 
role that solicitude plays if the crucial injury is the State's loss of land. After all, loss of property is a typical economic injury, and the Court went to great lengths to establish that the parties agreed on the likelihood of the injury. ${ }^{141}$ Indeed, the Court asserted:

[I]t is clear that petitioners' submissions as they pertain to Massachusetts have satisfied the most demanding standards of the adversarial process. EPA's steadfast refusal to regulate greenhouse gas emissions presents a risk of harm to Massachusetts that is both "actual" and "imminent." There is, moreover, a "substantial likelihood that the judicial relief requested" will prompt EPA to take steps to reduce that risk. ${ }^{142}$

To be sure, the Court qualified the just-quoted statement by noting that it was saying this "with [special solicitude] in mind," but it is hard to see how special solicitude pushed the case for standing over the edge if the submissions actually "satisfied the most demanding standards." ${ }^{143}$ On the other hand, to the extent that the real injury was "Massachusetts' stake in protecting its quasi-sovereign interests," 144 the Court's emphasis on the loss of coastline is quite inapposite. ${ }^{145}$

In sum, while Massachusetts clearly held that the State had standing, the Court's basis for that conclusion remains muddled. Both the nature of

141 See Jody Freeman \& Adrian Vermeule, Massachusetts v. EPA: From Politics to Expertise, 2007 SUP. CT. REV. 51, 67 (noting that the case featured "an ordinary standing analysis that focused on Massachusetts qua large landowner rather than qua sovereign, which found that Massachusetts's own coastal property was threatened by rising sea levels traceable to the effects of greenhouse gases," and that that analysis was "distinct from the 'special solicitude' holding"); see also Bradford Mank, Should States Have Greater Standing Rights than Ordinary Citizens?: Massachusetts v. EPA's New Standing Test for States, 49 WM. \& MARY L. REV. 1701, 1755 (2008) (“[W]ithout the relaxed immediacy and redressability standards of footnote seven or the special solicitude that the majority gave to states, the issue of whether Massachusetts met normal standing requirements is debatable.").

142 Massachusetts, 549 U.S. at 521 (quoting Lujan v. Defs. of Wildlife, 504 U.S. 555, 560 (1992); Duke Power Co. v. Carolina Envtl. Study Grp., Inc., 438 U.S. 59, 79 (1978)).

${ }^{143}$ Id. at 520-21; see also Mank, supra note 141, at 1707 ("The Court did not clearly explain whether Massachusetts could have met normal standing criteria or needed to rely on the special standing criteria for states.").

144 Massachusetts, 549 U.S. at 520.

145 The closest the Court came to drawing the two points together came when it stated: Just as Georgia's independent interest "in all the earth and air within its domain" supported federal jurisdiction a century ago, so too does Massachusetts' well-founded desire to preserve its sovereign territory today. That Massachusetts does in fact own a great deal of the "territory alleged to be affected" only reinforces the conclusion that its stake in the outcome of this case is sufficiently concrete to warrant the exercise of federal judicial power.

Id. at 519 (citation omitted) (quoting Georgia v. Tenn. Copper Co., 206 U.S. 230, 237 (1907)). There are problems with this reasoning: First, the Court's parallel between the State's "earth and air within its domain" and the State's "sovereign territory" elides the historic distinction between quasi-sovereign and direct injuries. Second, to the extent that parens patriae is the key to the State's ability to rely on land as the basis for standing, it is unclear how ownership of "a great deal" of that land "reinforces" the "concrete[ness]" of the injury. 
the injury ${ }^{146}$ and the role of special solicitude ${ }^{147}$ have continued to befuddle commentators.

\section{Commentators' Divergent Assessments}

The Court's splintered jurisprudence has led commentators to come up with various different descriptive, and normative, assessments of when a state can, and should, have standing to sue the federal government. Writing over two decades ago (and before Massachusetts $v$. EPA), Professors Woolhandler and Collins acknowledged the emergence of cases in which the Court allowed states to sue federal government actors but remained wary of the practice. They explained that the "prohibition against state suits seeking to vindicate a claim to govern to the exclusion of other sovereigns... reinforced federalism interests as well as strengthened individual rights and the separation of powers." ${ }^{148}$ And, in recent writing, Professor Woolhandler remains committed to this view. ${ }^{149}$ That said, she effectively concedes that the issue is not one of Article III standing, urging instead that "courts should decline to use their discretion to recognize such actions." 150

\footnotetext{
146 See, e.g., Calvin R. Massey, State Standing After Massachusetts v. EPA, 61 FLA. L. REv. 249, 264-65 (2009) ('[T]he Court stated that Massachusetts was asserting 'its rights under federal law,' a locution that suggests that Massachusetts' interest was either a proprietary interest or a sovereign interest.") (quoting Massachusetts, 549 U.S. at 520 n.17)); Amy J. Wildermuth, Why State Standing in Massachusetts v. EPA Matters, 27 J. LAND RESOURCES \& ENVTL. L. 273, 315-17 (2007) (critiquing the Court's treatment of injury in Massachusetts v. EPA).

147 See, e.g., Mank, supra note 141, at 1746 ("A major weakness in the Court's opinion is that it never explained to what extent it had relaxed standing requirements for states. It provided little or no guidance to lower courts about the degree to which they should give 'special solicitude' to states in deciding standing issues."); Gillian E. Metzger, Federalism and Federal Agency Reform, 111 CoLum. L. REV. 1, 67 (2011) (arguing that the "special solicitude" language "indicates the states should be accorded special access to federal court in order to challenge federal agency action"); see also Freeman \& Vermeule, supra note 141, at 67-68 (asserting that "[i]t seems obvious" that Justice Stevens included the "special solicitude" language - as well as the language about procedural rights - "at least in part ... [t]o garner [the] crucial fifth vote [of] Justice Kennedy").

148 See Woolhandler \& Collins, supra note 29, at 438-39.

149 See Woolhandler, supra note 29, at 236.

Existing remedies accommodate modern federalism; the judicial system traditionally sees private parties as having the paramount interest in contesting alleged governmental illegality; and the regulatory purposes of causes of action are served by traditional actions between government and individuals. In seeking recognition of sovereignty-based actions, moreover, the governmentplaintiff effectively asks the courts to extend the boundaries of both judicial and executive power, while undermining the role of individuals in challenging government illegality.

Id.

${ }^{150} I d$.
} 
Professor Vladeck seems more accepting of what I have termed the modern Court's direct-injury state standing cases. ${ }^{151}$ At the same time, he, like Professors Woolhandler and Collins, is dubious about further extensions of state standing to sue the federal government. ${ }^{152}$

Other commentators take a more expansive view of state standing to sue the federal government. Focusing on the holding in (if not the reasoning of) the Massachusetts case, they center on horizontal separation of powers as a basis for state standing to sue the federal government. Professor Gillian Metzger argues that, "given that Congress has disabled them from asserting regulatory authority in their own right, the states have a sovereign interest" - and therefore a basis for standing - "in ensuring that the federal government performs its regulatory responsibilities so that regulatory gaps are avoided." ${ }^{153}$ Professor Bradford Mank asserts that a state "should be able to file parens patriae suits on behalf of its citizens against the federal government if the federal government has allegedly failed to perform a statutory or constitutional duty." 154 Professor Calvin Massey argues in favor of a broad conception of state standing to assert parens patriae claims against the federal government based upon Executive Branch violations of constitutional and federal statutory law. ${ }^{155}$ And Professor Amy Wildermuth can be understood to have argued that Massachusetts suggests that states may have standing to challenge the manner in which the federal government implements federal law, where that implementation results in the preemption of state law. ${ }^{156}$

151 See supra note 29 and accompanying text. I note that Professor Grove suggests that the States in South Carolina v. Katzenbach and Oregon v. Mitchell were really arguing that the federal government had improperly preempted state law governing voter qualifications. See Grove, supra note 4, at 871-72.

152 See supra note 29 and accompanying text.

153 Gillian E. Metzger, Administrative Law as the New Federalism, 57 DUKE L.J. 2023, 2038 (2008); see also id. at 2037-39. Professor Metzger acknowledges both that such reasoning is not ultimately consistent with the majority opinion in Massachusetts, see id. at 2038-39, and that it is in any event subject to numerous objections, see id. at 2039.

154 Mank, supra note 141, at 1771 .

155 See Massey, supra note 146, at 276 (asserting that the argument against state standing to sue the federal government "ignores the fact that states ... are appropriate custodians of public rights, and state assertion of public rights in federal court does no more than ensure that executive discretion is confined within the boundaries of the Constitution and federal law"); id. at 284 ("EPA is a salutary breach of the hitherto impenetrable Maginot Line of standing that prevented judicial consideration of executive lawlessness which inflicts universal but impersonal harm on the citizens of our nation.").

156 Professor Grove characterizes Professor Wildermuth as having "argu[ed] that States may challenge not only federal preemption but also the manner in which a federal agency implements federal law." Grove, supra note 4, at 887 n.181 (citing Wildermuth, supra note 146, at 318-21). I am not so sanguine that this accurately captures Professor Wildermuth's argument. Professor Wildermuth argues that, had the Court in Massachusetts focused on the state of California instead of the state of Massachusetts, it would have easily found standing based on actual preemption of California law-i.e., a violation of its sovereign rights. Professor Wildermuth bases this conclusion on the fact that the Clean 
Professor Tara Leigh Grove takes the view that preemption of state law alone provides a sufficient basis for state standing to sue the federal government. ${ }^{157}$ She also rejects the notion that horizontal separation of powers has a role to play in the state standing calculus. ${ }^{158}$

Professor Shannon Roesler melds preemption of state law with the standing of states to challenge federal administrative programs. Professor Roesler argues that, "[b]ecause states cannot govern in many areas without confronting federal administrative law, they should be able to challenge federal laws and actions that are part of administrative regimes that contemplate an implementation role for the states." ${ }^{159}$ With this background principle as the driver, she proposes that, "when states seek to challenge federal laws and actions, they have Article III standing if the federal law at issue contemplates a role for state governments in its implementation." 160

Against this backdrop, I develop my description of sovereign preemption state standing to sue the federal government. I return to the

Air Act assures California of the opportunity (with a waiver from the EPA) to promulgate its own standards for motor vehicle emissions standards (with other states free to elect between California's standards and those promulgated by the EPA). Professor Wildermuth argues that, insofar as EPA declined to give California a waiver for standards for greenhouse gas emissions and that the EPA based this refusal to grant the waiver on the same reasoning it advanced in the Massachusetts case (i.e., that the EPA lacked the authority to regulate greenhouse gases at all), see Wildermuth, supra note 146 at 318-19, the relief requested in Massachusetts (i.e., a declaration that the EPA indeed had the statutory authority to regulate greenhouse gases) would perforce determine the preemption of state law. Had the relief not been granted, then (since the EPA would lack power to regulate greenhouse gas emissions), no waiver would have been needed and state law would not have been preempted. On the other hand, had relief been granted, then the EPA would have had the power to deny the waiver and thus preempt state regulatory authority. See Wildermuth, supra note 146, at 318-20. Thus, the injury to California was, Professor Wildermuth argued, purely "a sovereign one." Id. at 320. Seen in this light, Professor Wildermuth did not argue that federal implementation of federal law provides a basis for standing (or at least not generally, but only in the particular circumstances of the Clean Air Act under the facts of the Massachusetts case). But cf. Kathryn A. Watts \& Amy J. Wildermuth, Massachusetts v. EPA: Breaking New Ground on Issues Other than Global Warming, 102 Nw. U. L. REV. 1029, 1034 (2008) (“We ... think that when a state sues the federal government because federal law or administrative action regulates the state administrative machinery directly or otherwise undermines the state's independence in the federal system — such as, for example, by potentially preempting state law - the state may bring suit without reference to the [traditional standing] analysis.").

157 See Grove, supra note 4, at 880-85.

158 See id. at 885-99.

159 Roesler, supra note 33, at 677.

${ }^{160} I d$. at 678. Professor Roesler further elucidates:

Federal funding conditioned on state assistance in implementing federal law is enough, as is conditional preemption of state authority in a given area. The implementation role need not be substantial, although states will not likely challenge laws that have small impacts (e.g., a law that requires very little regulatory change at the state level). The federal law must do more than grant states civil and criminal enforcement authority ... it must contemplate that states will share in the day-to-day business of regulating by implementing federal policy through state administrative mechanisms and institutions.

Id. (footnote omitted). 
views of other commentators - in the context of a discussion of the consistency of their views with sovereign preemption state standingbelow in Section II.B.

\section{Describing SOVEREIGN PREEMPTION StATE StANDING TO SuE THE FEDERAL GOVERNMENT}

This Part introduces the concept of a state's sovereign preemption standing to sue the federal government. Section A develops sovereign preemption state standing as a functional approach to state standing and describes its essential elements. Section B explains how the concept is broadly consistent with existing Supreme Court precedent. Finally, Section $\mathrm{C}$ turns to nuances and ways that sovereign preemption state standing might be broadly or narrowly construed.

\section{A. The Function of States and Sovereign Preemption State Standing}

Undoubtedly separation of powers concerns arise when a state sues the federal government. The Court's penchant-when faced with competing parens patriae injuries - to reject jurisdiction on the ground that the conflict presents a political and not a judicial question, supports this assertion. ${ }^{161} \mathrm{~A}$ functional approach takes account of this concern by limiting standing to settings where a state seeks to vindicate a constitutionally preserved function. ${ }^{162}$

\section{The Constitutional Role of States}

The critical question in the separation of powers analysis becomes what constitutes a state's function under the Constitution. There are some relatively easy cases; as I above (and other commentators) have argued, in cases where the Constitution affords a state a direct injury, the courts can readily apply the traditional tripartite test for standing - including the usual understanding of what an injury in fact requires - to determine whether standing for the state is appropriate. In such a case, the courts need not depart from the traditional approach to standing, even though a sovereign state happens to occupy the role of plaintiff.

161 See supra notes 73-74 and accompanying text (describing Massachusetts v. Mellon, where the Court rejected the State's argument that its interest in regulating as a parens patriae should trump the federal government's analogous interest).

162 I have elsewhere propounded and defended a "functional" approach to defining the relevant injury other government entities - the Houses of Congress - can claim as a basis for standing. See Nash, supra note 36, at 368. There, I explained that a functional approach vindicates the constitutional design, while at the same time preserving the separation of powers concerns that undergird the importance of standing as a gatekeeper in this area. See id. 
However, that is not the whole picture. The constitutional scheme assigns certain responsibilities to states and assumes that states retain certain responsibilities that predate the Constitution but that the Constitution preserves. ${ }^{163}$ Interference by the federal government in a state's ability to fulfill these responsibilities imposes an "injury" on the state's functional role within the constitutional structure and should also meet the "injury in fact" requirement.

The notion that states should have a constitutionally protected function that can give rise to an injury should not be surprising. While the Constitution does not create the states (unlike the Houses of Congress), the Constitution clearly assumes their continued existence and incorporates states into the federal design. ${ }^{164}$

A major role for the states under the constitutional design is to ensure the continued health and well-being of their citizens. ${ }^{165}$ The surest route the Constitution uses to protect the state's ability to pursue this role is to preserve, in general, the state's prerogative to exercise its police power. ${ }^{166}$ This logic supports Professor Grove's argument that states have standing to challenge the validity of federal government efforts to preempt state law. ${ }^{167}$ While this argument is not (as I discuss below) inconsistent with sovereign preemption state standing, ${ }^{168}$ a state's standing to challenge federal preemption does not equate to, nor does it subsume, sovereign preemption

163 See, e.g., U.S. Term Limits, Inc. v. Thornton, 514 U.S. 779, 838-39 (1995) (Kennedy, J., concurring) ("The Framers split the atom of sovereignty. It was the genius of their idea that our citizens would have two political capacities, one state and one federal, each protected from incursion by the other. The resulting Constitution created a legal system unprecedented in form and design, establishing two orders of government, each with its own direct relationship, its own privity, its own set of mutual rights and obligations to the people who sustain it and are governed by it. It is appropriate to recall these origins, which instruct us as to the nature of the two different governments created and confirmed by the Constitution.").

164 See, e.g., Bond v. United States, 564 U.S. 211, 221 (2011) (“The allocation of powers in our federal system preserves the integrity, dignity, and residual sovereignty of the States. The federal balance is, in part, an end in itself, to ensure that States function as political entities in their own right."; cf. Alden v. Maine, 527 U.S. 706, 724 (1999) ("[T]he Constitution was understood, in light of its history and structure, to preserve the States' traditional immunity from private suits.").

165 See Alfred L. Snapp \& Son, Inc. v. Puerto Rico ex rel. Barez, 458 U.S. 592, 607 (1982) (surveying prior decisions to conclude that "a State has a quasi-sovereign interest in the health and wellbeing - both physical and economic - of its residents in general").

166 See, e.g., supra note 24 and accompanying text (discussing the Court's decision in Bond $v$. United States). Along similar lines, certain canons of construction applicable in federal court also recognize, and act to preserve, state legislative authority and core state functions. See, e.g., Medtronic, Inc. v. Lohr, 518 U.S. 470, 484-85 (1996) (describing the canon against preemption of state law); Gregory v. Ashcroft, 501 U.S. 452, 469-70 (1991) (describing the canon in favor of values of federalism).

167 See supra note 30 and accompanying text.

168 See infra note 195 and accompanying text. 
state standing. State standing to challenge the federal government's action is not limited to settings where the state challenges the legality of the federal government's effort at preemption; indeed, state standing may persist even after the courts have upheld the federal government's preemption of state law.

It is beyond cavil that the Constitution authorizes, and sometimes itself effects, the preemption of some state law. Upon entering the Union, the states delegated many powers to the federal government, including the power to preempt state law over additional areas of regulatory ambit. ${ }^{169}$ But this loss of power need not translate to a loss of function: Simply because a state lacks power directly to implement a regulatory response to a problem does not mean that it must abandon its function of trying to protect its citizenry from falling victim to that problem. An injury to the state's ability to ensure the protection of its citizens inures to the detriment of the citizens themselves; it is, in other words, an injury that should give the state parens patriae standing. In such settings, the state may have standing to challenge the federal government's decision to address a problem with one level (or type) of regulation (including no regulation) where the federal government has at the same time acted to preclude the state from exercising its own power to protect its citizens as it (the state) sees fit. ${ }^{170}$

\section{A Functional Approach}

The vertical separation of powers concerns described above may arise in many instances of preemption. That said, standing does not inhere in every instance of valid federal preemption of state law. Nor is it sufficient if the federal government in its stead chooses a level (or means) of protection different from that which the state, given its druthers, would have adopted. Indeed, two categories of settings leap to mind where this combination should not translate to a parens patriae injury.

First, under the constitutional design, states completely surrender some of their prerogatives to the national government. Some powers thus become entirely off-limits to the states because the Constitution delegates them solely to the federal government. For example, the Supreme Court has interpreted the Commerce Clause to preempt certain state regulation

\footnotetext{
169 See infra text accompanying notes 171-73.

170 See Massachusetts v. EPA, 549 U.S. 497, 519 (2007) ("When a State enters the Union, it surrenders certain sovereign prerogatives. Massachusetts cannot invade Rhode Island to force reductions in greenhouse gas emissions, it cannot negotiate an emissions treaty with China or India, and in some circumstances the exercise of its police powers to reduce in-state motor-vehicle emissions might well be pre-empted.").
} 
automatically, without any action on the part of the national government. ${ }^{171}$ As to such matters, the states have no function and, therefore, can suffer no injury ${ }^{172}$ _even if the federal government implements no regulation in the wake of the preemption, thus leaving a regulatory void.

Second, the Constitution has been interpreted to empower Congress to expropriate additional powers from the states beyond those already constitutionally assigned to the national government: For example, Congress has used the Commerce Clause as a basis for enacting federal environmental legislation that (to some degree at least) often preempts conflicting state law. ${ }^{173}$ In recognition of this fact, the Court historically declined to recognize a state's injury where it simply alleged that federal legislation was not in the state's interest or in the broad interest of its citizenry. ${ }^{174}$ As the Court routinely explained, the federal government fills the role of parens patriae as too do the states. ${ }^{175}$ The mere fact that two levels of government disagree about how (or sometimes even whether) to address a problem that affects some citizens does not mean that the state is not meeting its responsibility of protecting its citizens. After all, the duly elected representatives of the citizens in Washington and the duly elected representatives of the citizens in the state capital may have a different view of how to address a problem, ${ }^{176}$ and under the Constitution, the former will

171 See, e.g., Lewis v. BT Inv. Managers, Inc., 447 U.S. 27, 35 (1980) (“Although the [Commerce] Clause ... speaks in terms of powers bestowed upon Congress, the Court long has recognized that it also limits the power of the States to erect barriers against interstate trade.").

172 Of course, a state government and the federal government may contest the proper boundary of the automatic preemption, in which case a state would have standing to argue that its state regulation falls beyond the ambit of the dormant Commerce Clause's automatic preemption. See, e.g., Maine v. Taylor, 477 U.S. 131, 132-37 (1986) (holding that the State had standing to appeal a judgment reversing a conviction under a federal law that incorporated state law on the grounds that state law was preempted by the Commerce Clause, even where the federal government - the original prosecutorsided with the criminal defendant and agreed not to pursue appeal).

173 E.g., 42 U.S.C. \$7401(a) (2012) (Clean Air Act provision finding that air pollution often crosses state lines and has an impact on commercial values and activities); id. § 7543(a) (provision generally prohibiting states from imposing emissions-control requirements on new motor vehicles); see also Clean Air Mkts. Grp. v. Pataki, 338 F.3d 82, 89 (2d Cir. 2003) (holding that certain state law provisions were impliedly preempted by the Clean Air Act).

174 See supra notes 87-90 and accompanying text (discussing Massachusetts v. Mellon in this regard)

175 See supra note 88 and accompanying text (discussing Massachusetts v. Mellon).

176 As I have explained elsewhere:

[T] here may be a dispute between the federal and state governments as to the proper normative measure or approach [to the problem]. Perhaps the state government does not believe that costbenefit analysis should justify regulation, while the federal government does; or the state and federal governments agree on the validity of cost-benefit analysis, yet they disagree as to the assumptions underlying that analysis; or the state government takes a more precautionary approach than does the federal government. 
trump the latter. Moreover, as Professor Herbert Wechsler pointed out, the states themselves enjoy de facto representation in the Houses of Congress. ${ }^{177}$ A similar story unfolds where the Executive Branch validly receives from Congress, and exercises, the power to preempt state law. ${ }^{178}$

On the other hand, where the federal government has preempted state law and the Executive Branch modulates its administration of the laws enacted by Congress, the argument that the state has suffered an injury to its ability to protect its citizens is stronger (at least where the preemption prevents the state from acting on its own to remedy the situation). First, the claim that the federal government is clearly acting as the constitutionally authorized substitute parens patriae for the state is subject to doubt. To the extent that the Executive Branch has improperly substituted its choice of regulatory level for that of the Congress, there is an argument that the state's citizenry writ large has suffered an injury. ${ }^{179}$

Jonathan Remy Nash, Null Preemption, 85 Notre Dame L. ReV. 1015, 1019 (2010). See generally id. at $1052-62$.

177 See Herbert Wechsler, The Political Safeguards of Federalism: The Role of the States in the Composition and Selection of the National Government, 54 ColuM. L. REV. 543, 546-60 (1954); see also Nash, supra note 36, at 372.

178 Commentators are divided on whether agencies should have the power to preempt state law. Compare Nina A. Mendelson, A Presumption Against Agency Preemption, 102 Nw. U. L. REV. 695, 708-25 (2008) (arguing that institutional competence and separation of powers weigh in favor of Congress making preemption choices, and so the standard presumption against preemption should apply with even greater force against agency preemption), Thomas W. Merrill, Preemption and Institutional Choice, 102 Nw. U. L. REv. 727, 766-69 (2008) (contending that courts should uphold agency preemption only where Congress has delegated such authority), Mark D. Rosen, Contextualizing Preemption, 102 Nw. U. L. REV. 781, 796-800 (2008) (emphasizing, despite its shortcomings, Congress's institutional advantages in making preemption decisions), Robert R.M. Verchick \& Nina Mendelson, Preemption and Theories of Federalism, in PREEMPTION CHOICE: THE THeory, LAW, AND REALITY OF FEDERALISM's CORE QUESTION 13, 27 (William W. Buzbee ed., 2009) (taking a skeptical view of agency preemption), Ernest A. Young, Executive Preemption, 102 Nw. U. L. REV. 869, 871 (2008) (advocating restricting the freedom of agencies to preempt unilaterally), with Brian Galle \& Mark Seidenfeld, Administrative Law's Federalism: Preemption, Delegation, and Agencies at the Edge of Federal Power, 57 DUKE L.J. 1933, 1990 (2008) (arguing that agencies may be better positioned than Congress to decide whether preemption of state law is appropriate), Metzger, supra note 153, at 206972 (arguing that existing administrative law requirements may facilitate the inclusion of states' interests in administrative decisions), Catherine M. Sharkey, Products Liability Preemption: An Institutional Approach, 76 GEO. WASH. L. REV. 449, 477-502 (2008) (arguing in favor of agency reference of preemption decisions, with judicial review to ensure proper administrative process), and Catherine $\mathrm{M}$. Sharkey, What Riegel Portends for FDA Preemption of State Law Products Liability Claims, 103 Nw. U. L. REv. 437, 441-46 (2009) (making the same argument); see also William W. Buzbee, State Greenhouse Gas Regulation, Federal Climate Change Legislation, and the Preemption Sword, 1 SAN Diego J. Climate \& Energy L. 23, 26 (2009) (arguing in favor of an independent "Preemption Review Committee" that would render preemption decisions in problematic settings based on statutory criteria and record evidence).

179 See Massey, supra note 146, at 263-64; Nash, supra note 176, at 1072-73. 
Second, while the states enjoy some effective representation in the selection of the President, that representation pales in comparison to the state's effective representation in and influence over Congress. ${ }^{180}$ Thus, to the extent that the Executive Branch has indeed chosen-without proper authority-to implement a statute at a level different from that chosen by Congress, one would have greater concern that the constitutional design may be frustrated. After all, if one of the justifications for the delegation of power-even some police power traditionally exercised by the states-to the federal government is that that power would be exercised by a federal actor subject to the influence of the states-i.e., the Legislative Branchthe possibility that the Executive Branch is underexerting that appropriated power (at least as measured against Congress's wishes) raises a concern.

That standing arises out of the states' constitutional function explains why states sometimes may have standing to challenge Executive Branch underenforcement while private actors may not. Like states, private actors may be frustrated by Executive Branch underenforcement. Unlike states, however, private actors have no justiciable stake in the constitutional separation of powers. Indeed, the Court's assertion that states enjoy "special solicitude" in the standing calculus ${ }^{181}$ makes good sense when understood in this context. While the injury Executive Branch underenforcement inflicts on private actors is likely generalized and, therefore, insufficient to support standing, courts should afford "special solicitude" to states seeking to advance such claims by recognizing that Executive Branch underenforcement gives rise to an injury to a state's quasi-sovereign interests.

From a functional approach to state standing emerge the core elements for sovereign preemption state standing. First, the state must allege that the Executive Branch has underenforced the federal law in a way that is inconsistent with a governing statute. Second, the state must be able to point to preemption of state law. In particular, either the preemption of

180 See Massey, supra note 146, at 267 ("The method of electing Congress provides a "procedural safeguard' for state polities that is wholly absent with respect to administrative agencies."); Nash, supra note 36, at 372 ("Since the President is the only federal official elected nationwide - and indeed with a constituency that crosses any state boundary - the bulk of state political protection is provided by Congress (and perhaps especially by the Senate)."); Wechsler, supra note 177, at 558 ("It is in light of th[e] inherent tendency [of the government to preserve the domain of the states], reflected most importantly in Congress, that the governmental power distribution clauses of the Constitution gain their largest meaning as an instrument for the protection of the states. Those clauses, as is well known, have served far more to qualify or stop intrusive legislative measures in the Congress than to invalidate enacted legislation in the Supreme Court.").

181 Massachusetts v. EPA, 549 U.S. 497, 520 (2007); see supra text accompanying notes 142-147. 
state law must be obvious and clear from a federal statute; 182 the federal government must have previously sought, or be concurrently seeking, to preempt state law; or the preemption must otherwise already have been determined judicially. I refer to this as a "preemption exhaustion" requirement; such a threshold requirement makes sense because the underenforcement of federal law would not injure the state and its citizens were state law not preempted. ${ }^{183}$ Finally, there must be a nexus between the area of preemption and the area in which the Executive Branch is allegedly underenforcing federal law.

\section{B. Consistency of Sovereign Preemption State Standing with Existing Standing Precedent and Doctrine}

How does sovereign preemption state standing square with existing standing doctrine and prior precedent? The answer is that it squares rather well.

\section{Consistency with Precedent}

Consider first the consistency of sovereign preemption state standing with existing precedent on state standing to sue the federal government. The value of sovereign preemption state standing is readily apparent when we reconsider Massachusetts $v$. EPA. Lurking in the background of the litigation were the facts that (1) the Clean Air Act empowers California to promulgate its own motor vehicle emissions standards with a waiver from EPA $^{184}$ (which other states can then choose to follow in lieu of governing federal standards); ${ }^{185}$ (2) California had in fact requested a waiver from EPA to issue standards for motor vehicle greenhouse gas emissions; ${ }^{186}$ and (3) the same logic that motivated EPA to argue in the Massachusetts litigation that it lacked statutory authority to regulate motor vehicle greenhouse gas emissions also convinced it to decline to act on California's waiver request while the Massachusetts litigation was pending. ${ }^{187}$ In effect,

182 If the preemption is effected automatically by the Constitution, then the matter is something that the Constitution commits to the federal government, and the state can claim no injury in how the federal government (or the Executive Branch) decides to regulate in response to the matter.

183 Cf. Michael Sant'Ambrogio, Legislative Exhaustion, 58 WM. \& MARY L. REV. 1253, 1314-18 (2017) (arguing in favor of Congress first exhausting its opportunity to resolve a conflict with the Executive Branch nonjudicially as a prerequisite for congressional standing).

184 See 42 U.S.C. $\$ 7543$ (b) (2012). While not explicit, the wording of the statute authorizes only California to generate motor vehicle emissions standards. See Wildermuth, supra note 146, at 318.

185 See 42 U.S.C. $\$ 7507$ (2012); Wildermuth, supra note 146, at 318.

186 See Wildermuth, supra note 146, at 318-19.

187 See id. ("Although California applied for approval of its new standards in December 2005 the EPA would not consider California's request because California's regulation of greenhouse gas emissions was flatly inconsistent with the EPA's reading of [the Clean Air Act] in the decision under 
then, the Massachusetts case was litigated in the shadow of looming federal preemption of state police power (that Congress under the Clean Air Act had chosen to preserve). As language in the Court's opinion reflects, the Court understood Massachusetts's injury to result not from the preemption of state law but rather from the absence of regulation that would result from the combination of (a) preemption of the State's prerogative to regulate, and (b) the assertion of the federal government that, even while it precluded State regulation, it too lacked the power to regulate. ${ }^{188}$

Notably, while Professor Grove's theory - that preemption of state law provides a sufficient injury for the standing calculus - is fine as far as it goes, it offers no justification for the Court's conclusion in Massachusetts. After all, as Professor Grove herself points out in criticizing positions taken by Professor Metzger and by me, how could the injury be preemption of state law when, if the State obtained the relief it sought (in this case, obtaining a declaration that EPA could and should regulate motor vehicle greenhouse gas emissions), that injury would remain in place? ${ }^{189}$ Professor Grove's criticism misconstrues what I believe to be the relevant injury: the harm to the citizens of the State resulting from the regulatory void. ${ }^{190}$ Once one defines the injury thus, it is apparent that obtaining the relief the State sought would indeed address that injury.

review in Massachusetts." (footnote omitted)); see also id. at 319 ("[I]t is striking that when the Court ruled in favor of a different interpretation of [the Clean Air Act than that advanced by the EPA] and remanded the issue to the EPA, the EPA immediately changed its position. Two days after the Court's Massachusetts opinion was issued, the EPA announced that it would notice California's request and schedule both a public comment period and public hearings as required [by statute].”).

188 The Court explained:

When a State enters the Union, it surrenders certain sovereign prerogatives. Massachusetts cannot invade Rhode Island to force reductions in greenhouse gas emissions, it cannot negotiate an emissions treaty with China or India, and in some circumstances the exercise of its police powers to reduce in-state motor-vehicle emissions might well be pre-empted. These sovereign prerogatives are now lodged in the Federal Government, and Congress has ordered EPA to protect Massachusetts (among others) by prescribing standards applicable to the "emission of any air pollutant from any class or classes of new motor vehicle engines, which in [the Administrator's] judgment cause, or contribute to, air pollution which may reasonably be anticipated to endanger public health or welfare.

Massachusetts v. EPA, 549 U.S. 497, 519-20 (2007) (alteration in original) (citation omitted) (quoting 42 U.S.C. $\$ 7521(\mathrm{a})(1)(2012))$.

189 Professor Grove argues:

[I]n Massachusetts v. EPA, the State's sovereign injury-the inability to regulate-was caused not by the EPA's inaction, but by the provision of the Clean Air Act that prohibits Massachusetts from regulating motor vehicle emissions. And the only way to redress the State's sovereign injury was to lift the preemption - and thereby allow the State to "exercise ... its police powers" to regulate motor vehicle emissions itself. The State would continue to suffer the injury identified by Professors Metzger and Nash - the inability to regulate - no matter what the EPA did (or failed to do).

Grove, supra note 4, at 889 (footnotes omitted) (quoting Massachusetts, 549 U.S. at 519)

190 Instead, Professor Grove erroneously asserts that "the injury identified by Professor Metzger and Nash" was the State's "inability to regulate." Id. 
Beyond settings like Massachusetts, how does sovereign preemption state standing interact with, and affect, other areas where the courts have recognized state standing to sue the federal government? Here, it is important to understand the limited scope of sovereign preemption state standing. The doctrine would have no impact on cases where states allege direct injury and thus readily coexists with Professor Vladeck's acceptance of the holdings in those cases as relatively easy. ${ }^{191}$ The doctrine also in no way would change the result in any of the competing parens patriae cases above $^{192}$ : States still would not have standing in such cases. ${ }^{193}$

Nor would the doctrine impede the conclusion that standing inheres in cases where the state alleges an injury simply due to the preemption of its sovereign police powers (whether the Legislative or Executive Branches effected the alleged preemption). Thus, the conclusions that the States had standing in Missouri v. Holland and Colorado v. Toll would stand. ${ }^{194}$ Indeed, if Professor Grove is correct that the mere preemption of state law by the federal government should give rise to an injury sufficient to support standing, ${ }^{195}$ then the point of sovereign preemption state standing is to preserve the freedom of the state not only to seek to regain its lost police powers (by asserting preemption as its injury) but also to accept the preemption (or at least to accept an adjudication of the validity of the preemption) and to seek to force the federal government to live up to its obligation to regulate in its place.

\section{Consistency with Current Doctrine}

As discussed above, sovereign preemption state standing nicely complements Professor Grove's argument in favor of state standing to challenge the validity of the preemption of state law. In some sense, the latter will often be the precursor to the former. A determination that the federal government has properly preempted state law may leave the state with a basis to sue if the Executive Branch underenforces the federal law that Congress enacted to fill the void left by the state law preemption.

191 See supra note 29 and accompanying text.

192 See supra notes 86-90 and accompanying text.

193 In a competing parens patriae case, the State complains that the federal government's regulatory response to a problem inadequately protects the State's citizenry. Since there is no allegation in such a case that the federal Executive Branch is underenforcing federal law, there would be no sovereign preemption state standing.

194 See supra notes 91-104 and accompanying text.

195 I believe that Professor Grove is correct that mere preemption of state law is sufficient for standing, at least if the preempted state law goes to the state's police power. I conclude that Professor Grove's argument in the subsequent part of her Article relating to conflict over horizontal separation of powers is erroneous. 
In contrast, sovereign preemption state standing is entirely inconsistent with Professor Grove's argument that a state ought to have no standing to raise concerns of horizontal separation of powers. ${ }^{196}$ After all, sovereign preemption state standing is premised on the existence of Executive Branch underenforcement of federal statutory law. Professor Grove argues that the notion that a state could ever sue the federal government based on Executive Branch underenforcement "seems to rest on an assumption that States have a greater stake in the executive's compliance with federal statutes than other members of society-private parties, localities, and even Congress." ${ }^{197}$ But, as I explain below, sovereign preemption state standing does not require the states to have a greater stake in the executive's compliance with federal statutes. Rather, it stems from the idea that, because other actors may not have standing to challenge Executive Branch noncompliance, ${ }^{198}$ the state ought to have the chance to use its parens patriae authority to protects its constituents.

Beyond doctrinal analysis, Professor Grove tries to bolster her argument against state standing to challenge Executive Branch noncompliance by suggesting that the political aspirations of state attorneys general means that they "are not likely to be particularly savvy overseers of the federal executive's implementation of federal law." 199 Professor Grove thus advances the argument that, to the extent that state attorneys general are today more likely to bring suits for political reasons, ${ }^{200}$ functionalist grounds suggest that the federal courts should be less welcoming to these suits.

I find this argument unconvincing. First, as Professor Grove herself seems to concede, it seems odd to have the scope of standing enjoyed by a category of plaintiffs turn on the possible motivation of the plaintiffs' counsel. ${ }^{201}$ The injury (if one exists), and the right to vindicate it, belong to the state. That should not - and, it seems, legally cannot - change simply because a state has (as states generally have) chosen to vest the authority to

196 See Grove, supra note 4, at 885-99.

197 Id. at 892 (footnote omitted).

198 See infra notes 218-220 and accompanying text.

199 Grove, supra note 4, at 897.

200 See Cornell W. Clayton, Law, Politics and the New Federalism: State Attorneys General as National Policymakers, 56 REV. POL. 525, 538 (1994).

201 Professor Grove herself notes that her argument to limit state standing based on horizontal separation of powers conflicts "relies primarily on constitutional principle and precedent." Grove, supra note 4 , at 895 . That being the case, this portion of her argument-based as it is upon the presumed motivations of state lawyers filing suit - is an odd addition to Professor Grove's principal argument. 
bring suit in the person of an elected official. ${ }^{202}$ To put the point another way, whether a plaintiff has standing or not ought not to turn on the motivations (or speculation about the motivations) of the attorney bringing the suit. ${ }^{203}$ Second, to the extent that political aspirations may motivate state attorneys general to bring frivolous suits, they face sanctions for doing so (as do all attorneys who bring frivolous suits). ${ }^{204}$ Third, even if the argument might otherwise have weight, the factual predicate is far from clear; Professor Massey has argued to the contrary that the offices of state attorneys general actually "have limited resources and are politically constrained," 205 and as such will likely focus on "[o]nly particularly egregious executive violations of public rights." ${ }^{206}$ Finally, to whatever extent Professor Grove's concerns about state attorneys general prove true, sovereign preemption standing is narrow enough to allay concerns over the efforts of state attorneys general to rely on it more often than they should.

Finally, sovereign preemption state standing is not technically inconsistent with Professor Roesler's argument in favor of state standing to sue the federal government over a jointly administered federal program. ${ }^{207}$ On the other hand, my approach and Professor Roesler's rest on very different premises: On Professor Roesler's account, standing arises out of joint administration of regulatory programs by the state and federal governments. ${ }^{208}$ On my account, standing arises from a lack of agreement between the federal Executive and Legislative Branches, which runs to the detriment of the states' ability to protect their citizens. Moreover, if states could make use of both approaches, they could conceivably challenge a sizeable number of federal actions. Given the largely unrelated logical

\footnotetext{
202 Professor Grove does not explain why these same elected officials are better situated to assess when to bring actions challenging the preemption of state law (or, alternatively, why this concern does not figure into standing to challenge preemption).

203 It would similarly be odd to deny standing in class action cases because of a perception that counsel in those cases had ulterior motives for choosing to represent classes in those cases.

204 That the injury, and the claim associated with it, belong to the plaintiff state does not preclude the attorney representing the state from facing sanctions for bringing a frivolous claim. Provisions authorizing sanctions against attorneys contain no exception for state attorneys general. See, e.g., 28 U.S.C. $\$ 1927$ (2012) (authorizing sanctions against "[a]ny attorney or other person admitted to conduct cases in any court of the United States"); FED. R. CIV. P. 11(c) (authorizing sanctions against "any attorney, law firm, or party that violated the rule"); Husain v. Springer, No. 97 CV 2982(NG)(CLP), 2005 WL 1502897, at *3 (E.D.N.Y. June 24, 2005) (imposing nominal monetary sanctions against the Office of the New York State Attorney General under § 1927); Enriquez v. Estelle, 837 F. Supp. 830, 834 (S.D. Tex. 1993) (imposing monetary sanctions against the Attorney General of Texas).

205 Massey, supra note 146, at 274.

206 Id. at 279.

207 See supra text accompanying notes 159-60.

208 See id.
} 
underpinnings of the two arguments, it is not surprising that, as my discussion of particular cases below reveals, the classes of cases where states would have standing to sue the federal government under his conception of state standing and mine do not substantially overlap. ${ }^{209}$

Overall, sovereign preemption state standing squares nicely with existing precedent, as well as with current notions of state standing to sue the federal government.

\section{Consistency with Standing Doctrine's Function}

Does sovereign preemption state standing also square with the function of standing doctrine generally? The answer again is affirmative.

One purpose of standing is simply to limit the number of cases that reach the federal courts. ${ }^{210}$ Of course, if one disagrees with my argument above that sovereign preemption state standing is consistent with existing Court precedent, then one likely believes that the doctrine will expand the universe of cases that currently can be heard in federal court. Even then the number of additional cases will likely remain small. The requirements for sovereign preemption state standing are exacting. Moreover, the courts can apply the doctrine in a way that limits its availability only to settings where-as Professor Woolhandler suggests-Congress has explicitly authorized the plaintiff state's case by generating a statutory cause of action. ${ }^{211}$

Nor does the implementation of sovereign preemption state standing frustrate Professor Maxwell Stearns's argument that standing doctrine serves to discourage attempts by litigants to manipulate courts' dockets. ${ }^{212}$

209 I argue below that sovereign preemption state standing would be available in United States $v$. Texas but not in Virginia ex rel. Cuccinelli v. Sebelius, see infra Sections II.D.1-2, while Professor Roesler argued that the state should have standing in Virginia but not Texas, see Roesler, supra note 33, at 695-702.

210 See, e.g., F. Andrew Hessick, Probabilistic Standing, 106 Nw. U. L. REV. 55, 89 (2012) (noting that an "objection to expanding standing... is that it would open the floodgates of litigation and overburden the federal dockets").

211 See Woolhandler, supra note 29, at 212. Such a cause of action might currently be authorized by the Constitution or by the Administrative Procedure Act. See, e.g., 5 U.S.C. $\$ 702$ (2012) (granting a right to judicial review to a person affected by agency action). But see Armstrong v. Exceptional Child Ctr., Inc., 135 S. Ct. 1378, 1383-84 (2015) (holding that the Supremacy Clause does not give rise to a private right of action); Heckler v. Chaney, 470 U.S. 821, 828-35 (1985) (holding that the Administrative Procedure Act provides no private right of action to challenge an agency's exercise of its discretion not to act).

212 See Maxwell L. Stearns, Standing Back from the Forest: Justiciability and Social Choice, 83 CALIF. L. REV. 1309, 1323 (1995) (noting that standing is a "device used by federal courts to fend off challenges to governmental conduct that are brought primarily on an ideological basis"); see also Kenneth E. Scott, Standing in the Supreme Court-A Functional Analysis, 86 HARV. L. REV. 645, 67273, 683-85 (1973) (arguing that standing serves the purpose of rationing scarce judicial resources and defining the courts' policymaking role). See generally Maxwell L. Stearns, Standing and Social Choice: 
Once again, the requirements of the doctrine are too demanding to allow litigants - here, states - to bring suits in the hopes of manipulating the federal courts' dockets.

And, to the extent that one believes that a goal of standing doctrine is to validate the separation of powers among the branches of government, ${ }^{213}$ sovereign preemption state standing does not undermine that goal. Sovereign preemption state standing requires a true parens patriae injury to the state. The adversity between the parties is real, and the dispute does indeed resemble a case that might traditionally come before a court. ${ }^{214}$

\section{Nuances}

This Section discusses nuances that attend the recognition of sovereign preemption state standing. It first discusses the proper level of stringency for sovereign preemption state standing's nexus requirement. Second, it addresses how, and whether, sovereign preemption state standing might extend to cases of Executive Branch overenforcement (as opposed to Executive Branch underenforcement) of federal law. Third, the Section highlights that sovereign preemption state standing speaks to the outer boundaries of Article III standing and, thus, leaves Congress free not to provide standing under statutory causes of action it enacts. Finally, it discusses the interplay between sovereign preemption state standing and the bar against standing for generalized grievances.

\section{The Stringency of Sovereign Preemption State Standing's Nexus Requirement}

Sovereign preemption state standing requires a nexus between the area in which the federal government has preempted or is seeking to preempt state law and the area of law in which the Executive Branch is allegedly underenforcing federal law. But how close a nexus is required? If the areas of law must be identical, then sovereign preemption state standing will be rather narrow. Given the functional basis for sovereign preemption state standing, it makes more sense to look for substantial overlap between the goal of the law that the Executive Branch is allegedly underenforcing and

Historical Evidence, 144 U. PA. L. REV. 309 (1995) (drawing on historical evidence and case law to support point that standing doctrines prevent manipulation).

213 But see Heather Elliott, The Functions of Standing, 61 StAN. L. REV. 459, 474-75, 483-92, 497-500 (2008) (critiquing the notion that standing doctrine in fact can and should serve to validate separation of powers goals).

214 See, e.g., Flast v. Cohen, 392 U.S. 83, 95 (1968) (“"[T]he business of federal courts [is limited] to questions presented in an adversary context and in a form historically viewed as capable of resolution through the judicial process."). To the extent that separation of powers concerns are seen to preclude, or at least guard against, the assertion of generalized grievances, I argue below that sovereign preemption state standing does not run afoul of this notion. See infra Section II.C.4. 
the goal of the preempted state law. To be sure, any such analysis is bound to be somewhat subjective. Still, the success courts have had with similar inquiries - consider the definition of the relevant "field" of law in deciding whether Congress has effected "field preemption" 215 _ suggests that the courts would be well positioned to undertake such an analysis in this setting.

\section{Should Sovereign Preemption State Standing Extend to Cases of} Executive Overenforcement of Federal Law?

As I have described sovereign preemption state standing to this point, it permits a state to allege that the Executive Branch has underenforced existing federal statutory law. But should such standing also apply where the state alleges an overenforcement of federal law by the Executive Branch, i.e., wherever the state can allege a difference between Congress's enforcement expectations (as expressed in the governing statute) and the Executive Branch's enforcement practices? Indeed, one might criticize the narrower version of sovereign preemption state standing as biased in favor of obtaining increasing levels of regulation.

While it would not be inconceivable to have a broader conception of sovereign preemption state standing that embraces alleged Executive Branch overenforcement of federal law, there are justifications for adhering to the narrower conception. First, the functional justification for sovereign preemption state standing is to ensure that the state's police power does not go underutilized, even when expropriated by the federal government. But the essence of the police power consists of the power affirmatively to regulate, not the power to abstain from regulation. ${ }^{216}$ It thus ought not to be surprising that a valid conception of sovereign preemption state standing might be biased in favor of generating more regulation.

Second, concerns of democratic accountability give rise to a related justification for restricting sovereign preemption state standing to cases of alleged Executive Branch underenforcement. To the extent that a problem facing the state falls within the scope of problems ordinarily dealt with by

215 See, e.g., S. Candice Hoke, Preemption Pathologies and Civic Republican Values, 71 B.U. L. REV. 685, 744-47 (1991) (discussing how courts are equipped-in cases where field preemption is at issue - to deal with arguments by parties, and ambiguity over what the relevant field of law is). Consider as well the analysis courts undertake in an antitrust case to determine the "relevant market." See generally Gregory J. Werden, The History of Antitrust Market Delineation, 76 MARQ. L. REV. 123 (1992). The nexus inquiry I set out here would also invite courts to engage in a form of purposivism, despite the drift of judges in recent decades away from purposivism and toward textualism. Still, that some purposivist analysis might be involved is not surprising given the role of preemption in the sovereign preemption state standing analysis. See generally Note, Preemption as Purposivism's Last Refuge, 126 HARV. L. REV. 1056 (2013)

216 See supra note 166 and accompanying text. 
the state government, the citizens of a state reasonably might not understand that the state government was disempowered from acting ${ }^{217}$ or that the Executive Branch was responsible for underenforcing the federal legislature's directive. On the other hand, it is harder to see how the citizens of a state might blame state government for the Executive Branch's overenforcement of federal law.

A third and final justification, is the general point (perhaps prudential) that it is less important to stretch standing doctrine to recognize a plaintiff's standing where another plaintiff has clear standing. ${ }^{218}$ The Court has made this point in particular in the context of would-be governmental plaintiffs, noting the reduced need to find standing for such plaintiffs where a "private plaintiff" likely has standing to raise the same issue. ${ }^{219}$ Settings of alleged overregulation will more likely generate private plaintiffs directly affected by the allegedly overregulatory behavior ${ }^{220}$ than will settings of underregulatory behavior. For that reason, states need less opportunity to challenge Executive Branch overenforcement. By contrast, the likely absence of a private plaintiff in cases of alleged Executive Branch underenforcement supports state standing.

\section{Sovereign Preemption State Standing Meets the Article III Standard but Does Not Speak to Statutory Standing}

The functional considerations on which sovereign preemption state standing rests relate to Article III standing. The fact that a state has sovereign preemption standing says nothing about whether the state has valid standing under a congressional statute (any more than the fact that a statutory grant of state standing would negate the Article III standing

217 Cf. New York v. United States, 505 U.S. 144, 169 (1992) (“Accountability is thus diminished when, due to federal coercion, elected state officials cannot regulate in accordance with the views of the local electorate in matters not pre-empted by federal regulation.”).

218 See, e.g., Hein v. Freedom From Religion Found., Inc., 551 U.S. 587, 614 (2007) (plurality opinion) (" $[R]$ espondents make no effort to show that these improbable abuses could not be challenged in federal court by plaintiffs who would possess standing based on grounds other than taxpayer standing.").

219 See Raines v. Byrd, 521 U.S. 811, 829-30 (1997) (noting that holding that members of Congress lacked standing did not "foreclose[] the Act from constitutional challenge (by someone who suffers judicially cognizable injury as a result of the Act)," while also observing that the Court "need not now decide" whether the outcome would have been different were a private plaintiff unavailable or unable to proceed); cf. South Carolina v. Regan, 465 U.S. 367, 380-81 (1984) (holding that the AntiInjunction Act should not apply to preclude state suit, reasoning that even though in theory a private plaintiff still could bring suit and raise the same question, "it is by no means certain that the State would be able to convince a [private party] to raise its claims").

${ }^{220}$ See infra text accompanying note 263. 
requirement ${ }^{221}$ ). I note that my conception of sovereign preemption state standing is consistent with the notion, advanced by Professor Woolhandler, ${ }^{222}$ that federal courts should decline to exercise jurisdiction to hear a state's claim unless a statute authorizes the federal courts to hear the claim. ${ }^{223}$

\section{The Interplay Between Sovereign Preemption State Standing and the Bar Against Standing for Generalized Grievances}

The Supreme Court has explained that a party generally has standing only for "particularized grievances," and not for generalized grievances that are shared by too many citizens. ${ }^{224}$ One could take the position that the bar against generalized grievances applies as well in the context of sovereign preemption state standing.

Scholars debate whether the bar against standing for generalized grievances is constitutional or merely prudential. ${ }^{225}$ To the extent it is merely prudential, it does not pose an insurmountable obstacle to sovereign preemption state standing. Indeed, one might interpret the Massachusetts Court's invocation of the "special solicitude" of the states in the standing calculus as a suggestion that the generalized grievance prudential restriction should not apply in cases of state standing 226 (or at least in cases of sovereign preemption state sanding).

On the other hand, even if the "particularized grievance" requirement does apply in sovereign preemption state standing cases (whether because the requirement is constitutional, or because, though prudential, courts should generally apply the doctrine even to assertions of standing by

221 To put this another way, Congress cannot grant standing beyond that which Article III authorizes. See, e.g., Lujan v. Defs. of Wildlife, 504 U.S. 555, 580 (1992) (Kennedy, J., concurring) ("The Court's holding that there is an outer limit to the power of Congress to confer rights of action is a direct and necessary consequence of the case and controversy limitations found in Article III.").

222 See supra note 211 and accompanying text.

223 Other subconstitutional standing doctrines are similarly consistent with sovereign preemption state standing. See Massey, supra note 146, at 279 (arguing that the political question doctrine can be applied in cases where states rely on parens patriae standing); infra text accompanying note 225 (discussing the possibility that the "bar" against standing for generalized grievances is subconstitutional).

224 See, e.g., Allen v. Wright, 468 U.S. 737, 755-56 (1984) (rejecting an "abstract stigmatic injury ... [that] would extend nationwide to all members of the particular racial groups against which the Government was alleged to be discriminating").

225 For discussion, see e.g., Nash, supra note 44, at $1305 \&$ n.132. For a discussion of how the Court has variously treated the requirement as constitutional and prudential, see Craig A. Stern, Another Sign from Hein: Does the Generalized Grievance Fail a Constitutional or Prudential Test of Federal Standing to Sue?, 12 LEWIS \& ClARK L. REV. 1169, 1204-17 (2008).

226 See, e.g., Bradford C. Mank, Prudential Standing Doctrine Abolished or Waiting for a Comeback?: Lexmark Int'l, Inc. v. Static Control Components, Inc., 18 U. PA. J. CONST. L. 213, 238 (2015) (making such a suggestion). 
states), and even if the "particularized grievance" requirement acts to preclude many cases where sovereign preemption state standing would otherwise apply, the doctrine still would have significant purchase. This is because there remain cases where some states actually have particularized claims, i.e., have parens patriae claims that other states do not.

Indeed, the two cases I discussed in the Introduction provide examples of settings where sovereign preemption state standing might apply ${ }^{227}$ and where some state plaintiffs would have particularized claims. Consider first the setting of global warming as exemplified in Massachusetts v. EPA. Leaving to the side the fact that the Court there seemed to rely on Massachusetts' actual ownership of coastline that would disappear with rising sea levels resulting from global warming, the fact remains that coastal states face far more of a risk from global warming than inland states. ${ }^{228}$ Indeed, some states in the plains may actually benefit from some degree of global warming. ${ }^{229}$ In short, Louisiana and Florida could have alleged particularized injuries as a result of EPA's failure to regulate greenhouse gas tailpipe emissions. ${ }^{230}$

United States v. Texas addresses allegations by numerous states that the Executive Branch improperly underenforced the immigration laws. And in the context of illegal immigration, the Supreme Court has previously recognized that some states bear greater harm than others. ${ }^{231}$ These states presumably could satisfy the particularized grievance requirement.

\section{Applying Sovereign Preemption State Standing}

How might sovereign preemption state standing apply in disputes recently and currently before the courts? This Part explores how sovereign preemption state standing would apply, or not apply, in actual cases (and in

\footnotetext{
227 See supra notes 7-22 and accompanying text.

228 See, e.g., Susan Muller, Unprecedented Harm: Will the Roberts Court Recognize the Distinction Between Global Warming and Its Effects?, 44 NEW ENG. L. REV. 317, 338 (2010) (“A perhaps more obvious feature of sea level rise is that it has no impact on people living away from coasts, while people living on coasts and owners of coastal property are affected in a very concrete and personal way ....").

229 See, e.g., Cass R. Sunstein, Of Montreal and Kyoto: A Tale of Two Protocols, 31 HARV. EnVTL. L. REv. 1, 33 (2007) (“On some estimates, American agriculture will actually be a net winner as a result of climate change.").

230 See also supra note 156 (discussing Professor Wildermuth's argument that California was in a unique position to sue the EPA for its failure to regulate tailpipe greenhouse gas emissions, given the special status that California enjoys under the Clean Air Act to promulgate motor vehicle emissions standards).

${ }^{231}$ See De Canas v. Bica, 424 U.S. 351, 357 (1976) (noting that "local problems" associated with the employment of illegal immigrants "are particularly acute in California in light of the significant influx into that State of illegal aliens from neighboring Mexico.").
} 
one hypothetical case based on an actual case) recently brought before the federal courts.

\section{State Standing in United States v. Texas}

Consider first United States v. Texas. ${ }^{232}$ As noted above, the Court affirmed, by tie vote, the existence of Texas's standing to challenge the alleged underenforcement of the federal immigration laws by the Obama Administration. ${ }^{233}$ As also noted above, Texas did what it could to define its injury in terms of the existing pigeonholes of direct injury to the Statethere, the cost of issuing more driver's licenses - and of injury to a truly sovereign interest, the issuance of driver's licenses. ${ }^{234}$

Sovereign preemption state standing provides a better fit. The regulation of immigration is a core police power that the states have largely ceded to the federal government. Indeed, the federal government recently relied on the federal courts to validate a strong understanding of the preemption of state powers in the area. In 2010, Arizona enacted the Support Our Law Enforcement and Safe Neighborhoods Act (the Arizona law) with the express goal of "discourag[ing] and deter[ring] the unlawful entry and presence of aliens and economic activity by persons unlawfully present in the United States." ${ }^{235}$ The Obama Administration opposed the Arizona law from its enactment ${ }^{236}$ and promptly filed suit against the State to enjoin the law's implementation. ${ }^{237}$

The litigation ultimately reached the U.S. Supreme Court, which largely accepted the federal government's argument that federal law preempted the Arizona law. 238 The Court held that federal law preempted Arizona law provisions that (1) made it a misdemeanor under state law to fail to comply with federal alien-registration requirements, ${ }^{239}$ (2) made it a misdemeanor under state law for an alien without authority to be in the United States to seek, or engage in, work in Arizona, ${ }^{240}$ and (3) authorized a

${ }^{232}$ Texas v. United States, 86 F. Supp. 3d 591 (S.D. Tex. 2015), aff'd, 809 F.3d 134 (5th Cir. 2015), aff'd by an equally divided Court, 136 S. Ct. 2271 (2016).

233 See supra note 18 and accompanying text.

234 See supra text accompanying notes 16-17.

235 See Arizona v. United States, 132 S. Ct. 2492, 2497 (2012) (quoting ARIZ. REv. STAT. AnN. $\S 11-1051$ editor's note (2012)).

236 See Sheryl Gay Stolberg, Advocates of an Immigration Overhaul Question a Border Deployment, N.Y. TIMES, May 27, 2010, at A22 ("Mr. Obama ... condemned [the Arizona Law] on the day it was signed into law.").

237 See United States v. Arizona, 703 F. Supp. 2d 980 (D. Ariz. 2010), aff'd, 641 F.3d 339 (9th Cir. 2011), aff'd in part, rev'd in part, 132 S. Ct. 2492 (2012).

238 See Arizona, 132 S. Ct. at 2501-10.

239 See id. at 2501-03 (discussing ARIz. Rev. StAT. AnN. § 13-1509 (2011)).

240 See id. at 2503-05 (discussing ARIz. REV. STAT. ANN. § 13-2928(C) (2011)). 
police officer in the state to arrest without a warrant a person whom "the officer has probable cause to believe... has committed any public offense that makes the person removable from the United States." ${ }^{241}$

Given the preemption backdrop, the subsequent lawsuit by Texas sought to protect the citizens of the states from the regulatory gap that would, Texas argued, result from the underenforcement of the law by the federal government. The only question possibly hindering the applicability of sovereign preemption state standing is whether a sufficient nexus existed between the federal government's preemption of state law, on the one hand, and the area of alleged underenforcement of federal law on the other. One might argue that the Arizona criminal law and law enforcement provisions that the Supreme Court invalidated differed in kind from the immigrationstatus laws that the Executive Branch had allegedly underenforced through its issuance of DAPA. It seems, however, that a strong argument can be made that the Arizona case vindicated the Executive Branch's desire to minimize the states' role in immigration enforcement, while the issuance of DAPA allegedly reflected the underenforcement of federal immigration law. ${ }^{242}$ If so, then sovereign preemption state standing would apply.

2. State Standing in Virginia ex rel. Cuccinelli v. Sebelius

Consider next the case of Virginia ex rel. Cuccinelli v. Sebelius, ${ }^{243}$ where the State of Virginia, acting through its Attorney General, sought to challenge the federal Affordable Care Act (ACA) on the ground that the ACA's "individual mandate"-which requires individuals to purchase health insurance coverage or pay a penalty ${ }^{244}$-was an unconstitutional exercise of Congress's power to regulate interstate commerce. As its injury, Virginia pointed to the preemption of a provision of its law-enacted contemporaneously with the ACA - that provided that "[n]o resident of this Commonwealth ... shall be required to obtain or maintain a policy of individual insurance coverage." ${ }^{245}$ Here, sovereign preemption state

${ }^{241}$ Id. at 2498 (quoting ARIZ. REV. STAT. ANN. § 13-3883(A)(5) (2011)); see id. at 2505-07 (discussing that provision of the Arizona law). The Court also expressed suspicion over the viability of a fourth provision, see id. at 2509-10, one that provided that "officers who conduct a stop, detention, or arrest must in some circumstances make efforts to verify the person's immigration status with the Federal Government," id. at 2498 (discussing ARIZ. REV. STAT. ANN. § 11-1051(B) (2012)). The Court did not, however, declare that provision completely preempted. See id. at 2507-10 (discussing ARIZ. REV. STAT. ANN. § 11-1051(B) (2012)).

242 To the extent that the bar against generalized grievances is applicable in sovereign preemption state standing cases, the grievance in United States v. Texas is likely sufficiently particularized. See supra text accompanying note 231 .

243656 F.3d 253 (4th Cir. 2011)

244 See 26 U.S.C. § 5000A(a)-(b) (2012).

245 VA. CODE ANN. § 38.2-3430.1:1 (2017). 
preemption would not provide a basis for standing (and thus would not change the result in the case ${ }^{246}$ ). Virginia did not meet either prong of the doctrine. First, no issue of horizontal separation of powers existed: Virginia challenged Congress's ability to enact the ACA's individual mandate in the first place. In that sense, the alleged injury was really a "competing parens patriae" assertion, which remains ineffective to establish standing. ${ }^{247}$ Indeed, Virginia made no allegation in the case that the Executive Branch was underenforcing federal law.

Second, even if Virginia had somehow raised a horizontal separation of powers issue, the Commonwealth had not met the preemption exhaustion requirement: the governing federal statute did not clearly and obviously preempt Virginia law, and neither the State nor the federal government took affirmative steps to determine whether Virginia law was actually preempted. ${ }^{248}$ In order for the possibility of a regulatory gap to be imminent and nonconjectural, sovereign preemption state standing requires that the preemption of state law be real and not just hypothetically predicted. Here such imminence simply did not exist.

\section{Oregon's Claim in the Gonzales v. Oregon Litigation}

Third, consider the dispute in Gonzales v. Oregon ${ }^{249}$ over Oregon's Death with Dignity Act (ODWDA) ${ }^{250}$ In order to achieve the statutory goal of authorizing physician-assisted suicide and insulating physicians who assisted in suicides, the ODWDA "exempts from civil or criminal liability state-licensed physicians who, in compliance with the specific safeguards in ODWDA, dispense or prescribe a lethal dose of drugs upon the request of a terminally ill patient." ${ }^{251}$ This, however, led to a possible conflict with federal law, since the federal Controlled Substance Act (CSA) regulated the drugs that physicians prescribed under the ODWDA. ${ }^{252}$ The CSA groups

\footnotetext{
${ }^{246}$ In the actual litigation, the United States Court of Appeals for the Fourth Circuit found that Virginia did not have standing to proceed. 656 F.3d at 269-73.

${ }^{247}$ In effect, the Virginia case is the flip of what I call "null preemption." Null preemption arises when the federal government preempts state law and, by enacting nothing to fill the resulting gap, leaves in its wake a regulatory void. See Nash, supra note 176, at 1039-47. Here, by contrast, it is the State that prefers a regulatory void, while the federal government believes that regulation is the answer. The simple constitutional answer is that, per the Supremacy Clause, Congress wins the battle between the sovereigns.

248 On the question of whether the state had standing simply to challenge the preemption of state law, Professor Grove explains, along somewhat similar lines, "I argue ... that to the extent a state law merely declares that private citizens are not subject to legal requirements, and does not seek to regulate private citizens, that is not sufficient for standing purposes." Grove, supra note 4, at 877 .

249546 U.S. 243 (2006).

250 See OR. Rev. STAT. $\S 127.800-897$ (2015); Gonzales, 546 U.S. at 249.

251 Gonzales, 546 U.S. at 249.

25221 U.S.C. §§ 801-904 (2012).
} 
drugs into categories, or "schedules"; the schedule on which the drugs in question appears renders that drug dispensable by a physician only directly or by way of a prescription. ${ }^{253}$ The CSA authorizes the Attorney General by regulation to modify the schedule of drugs. ${ }^{254}$ A 1971 regulation authorizes physicians to dispense the drugs in question "for a legitimate medical purpose." ${ }^{255}$ The CSA also sets up a registry for physicians; only registered physicians may dispense regulated drugs. ${ }^{256}$ Finally, the CSA includes a provision confirming the continuing role of states in regulating in the area, calling for the displacement of state law only where "there is a positive conflict between that provision of this subchapter and that State law so that the two cannot consistently stand together." ${ }^{257}$

In 2001, the Attorney General issued an interpretive rule that cast doubt on the continued vitality of the ODWDA. ${ }^{258}$ The rule declared that "assisting suicide is not a 'legitimate medical purpose' within the meaning" of the Attorney General's 1971 regulation. ${ }^{259}$ Dispensing the drugs in question, therefore, would constitute a violation of the CSA, and a physician who in fact dispensed such drugs under the ODWDA would put his or her registration at risk. ${ }^{260}$ Finally, the interpretive rule expressly endeavored to displace state law, explaining that "[t]he Attorney General's conclusion applies regardless of whether state law authorizes or permits such conduct by practitioners or others." ${ }^{261}$

Would sovereign preemption state standing have provided a basis for Oregon's standing in the Gonzales v. Oregon litigation? ${ }^{262}$ No, unless the doctrine extends to Executive Branch overenforcement of federal law. Undoubtedly the interpretive rule explicitly sought to preempt state law. But Oregon's complaint was not that the Executive Branch was underenforcing the CSA but rather that it was overenforcing it by extending its reach to apply to actions otherwise protected under the ODWDA.

\footnotetext{
${ }^{253} I d . \S 829$ (a)-(b).

254 Id. $\S 811(\mathrm{a})$.

25521 C.F.R. $\S 1306.04$ (a) (2016).

256 See 21 U.S.C. $\$ \S 822-824$ (2012).

257 Id. $\S 903$.

258 Dispensing of Controlled Substances to Assist Suicide, 66 Fed. Reg. 56,607 (Nov. 9, 2001).

259 Id. at 56,608 .

$260 I d$.

261 Id.

${ }^{262}$ In the actual case, the Supreme Court did not address standing. See Grove, supra note 4, at 873 n.118. The district court did address the state's standing, and concluded that standing was proper. See Oregon v. Ashcroft, 192 F. Supp. 2d 1077, 1087 (D. Or. 2002). However, the Ninth Circuit easily found that intervening health care practitioners had standing, see Oregon v. Ashcroft, 368 F.3d 1118, 1121 \& n.2 (9th Cir. 2004), which obviated the need to address any other plaintiff's standing. The Supreme Court presumably relied on this conclusion.
} 
Indeed, the actual procedural history of the Gonzales v. Oregon litigation highlights one of the reasons I offered above for why sovereign preemption state standing is not needed in cases of alleged Executive Branch overenforcement: In the actual litigation, there were-as one would generally expect in the setting of overenforcement-private parties who could establish standing under the traditional test. ${ }^{263}$

\section{A Lawsuit by Nebraska and Oklahoma Against the Federal Government Arising out of Colorado's Decriminalization of Recreational Marijuana}

Finally, consider a lawsuit that has yet to be brought but that would arise out of the same dispute that has generated the Nebraska v. Colorado litigation. ${ }^{264}$ In the actual case, Nebraska and Oklahoma sought to sue Colorado under the Supreme Court's original jurisdiction, alleging that Colorado's legalization of recreational marijuana ${ }^{265}$ had led to an influx of marijuana into the plaintiff States and had generated high criminal enforcement costs. ${ }^{266}$ The Court declined the plaintiff Sates' request to exercise its original jurisdiction. ${ }^{267}$ One could imagine, however, that the plaintiff States might have thought of suing additionally (or instead) the U.S. Attorney General, given that the Attorney General's response to Colorado's legalization decision suggested as a matter of policy that enforcement resources should be deployed with an eye to local legalization laws. ${ }^{268}$ If Oklahoma had sued the Attorney General, would sovereign preemption state standing apply?

No, the theory of sovereign preemption state standing outlined in this Article would not grant Oklahoma standing in this hypothetical litigation. To see this, note that the plaintiff States could not allege federal preemption

\footnotetext{
263 See text accompanying supra note 220.

264 Nebraska v. Colorado, 135 S. Ct. 2070 (2015) (invitation for Solicitor General to file a brief expressing the views of the United States); see also Nebraska v. Colorado 136 S. Ct. 1034 (2016) (denial of motion for leave to file a bill of complaint).

265 Were the issue the legalization of medical marijuana, there clearly would be no sovereign preemption state standing, because Congress itself has approved - indeed to some degree mandatedthe underenforcement of federal criminal drug laws in that context. Specifically, through riders to appropriations bills, Congress has since 2014 prohibited the Department of Justice from using any of the funds allocated to it in a way that would "prevent" a state from implementing state laws "that authorize the use, distribution, possession, or cultivation of medical marijuana." United States v. McIntosh, 833 F.3d 1163, 1169 (9th Cir. 2016) (citation omitted); id. at 1179 (allowing criminal defendants an injunction against prosecutors based on these funding restrictions).

266 See Complaint at III 7, 54-68, Nebraska v. Colorado, 135 S. Ct. 2070 (2015) (No. 144, Orig.).

267 Nebraska v. Colorado, 136 S. Ct. 1034 (2016).

268 See, e.g., Todd Grabarsky, Conflicting Federal and State Medical Marijuana Policies: A Threat to Cooperative Federalism, 116 W. VA. L. REV. 1, 23-24 (2013).
} 
of their laws; rather, they would allege — and indeed have alleged — that federal law effected preemption of a sister state's law.

To be sure, the plaintiff States could allege that the Executive Branch had unilaterally decided to underenforce governing federal law. But the ability to allege a problem of horizontal separation of powers, while necessary, is not sufficient to satisfy the requirements of sovereign preemption state standing. Sovereign preemption state standing rests on the notion that the Executive Branch is underutilizing powers that the states delegated to the federal government and that Congress in turn directed the Executive Branch to employ. In contrast, preconstitutionally, no state had the legal power to restrict a neighboring state's exercise of its own police powers. Indeed, as the Court noted in its 1906 decision in Missouri v. Illinois, the interstate lawsuit that the Constitution created stands as a substitute for diplomacy or the use of force. ${ }^{269}$ Since a state never had the power and, therefore, did not delegate to the federal government the power, to compel a sister state to exert its own police powers, neither does it have sovereign preemption state standing to challenge the federal government's failure to inhibit the sister state's behavior in this regard.

In so concluding, I do not mean to argue that there is no theory under which the plaintiff States might have standing to sue the federal government. Perhaps there are other theories of standing that might apply. ${ }^{270}$ My point is simply to show that sovereign preemption state standing does not apply and, in so doing, to demonstrate the limits of the doctrine.

\section{CONCLUSION}

In this Article, I have introduced and explicated the doctrine of sovereign preemption state standing. First, the state must allege that the Executive Branch has underenforced the federal law in a way that is inconsistent with a governing statute. Second, the state must be able to

269200 U.S. 496, 518 (1906) (describing a lawsuit between states as "a situation which, if it arose between independent sovereignties, might lead to war"). In effect, the Constitution removes a state's prerogative to go to war with another state but creates for it the opportunity to sue the other state in court.

270 Of note in this regard is the Court's suggestion in Massachusetts v. EPA that states effectively surrender their power to invade sister states in order to address transboundary issues. That may indeed in some sense obligate the Executive Branch to apply federal law so as to minimize transboundary effects. See supra note 170 and accompanying text. Alternatively, Congress might create a statutory cause of action to cover interstate spillovers from marijuana legalization. Cf. 42 U.S.C. $§ 7426$ (2012) (Clean Air Act provision empowering states and subdivisions thereof to petition EPA for relief to the extent that a stationary source or a group of stationary sources in another state allegedly emits regulated pollutants to a degree that the emissions contribute significantly to the petitioning entity's failure to comply with federal air quality standards). 
point to preemption of state law; in particular, either the preemption of state law must be obvious and clear from a federal statute or the federal government must have previously sought, or be concurrently seeking, to preempt state law. In addition, there must be a nexus between area of preemption and the area in which the Executive Branch is allegedly underenforcing federal law.

Sovereign preemption state standing rests on a functional understanding of the injury a state suffers when the federal government precludes it from regulating in an area and then the Executive Branch provides underenforcement of the governing federal statutory law. The doctrine squares well with precedent and makes sense of some precedent that has to this point flummoxed lower courts and commentators. Sovereign preemption state standing complements other settings where states have standing to sue the federal government. Finally, the doctrine can be overlaid with various prudential standing doctrines, which further would narrow the scope of the doctrine. 
N O R T H W ESTER N U N IVER S T Y LA W R E V IE W 